\title{
Archaeological Testing and Monitoring in Connection with a Drainage Project at Mission San Juan Capistrano San Antonio, Bexar County, Texas
}

Anne A. Fox

Center for Archaeological Research

Follow this and additional works at: https://scholarworks.sfasu.edu/ita

Part of the American Material Culture Commons, Archaeological Anthropology Commons, Environmental Studies Commons, Other American Studies Commons, Other Arts and Humanities Commons, Other History of Art, Architecture, and Archaeology Commons, and the United States History Commons

Tell us how this article helped you.

This Article is brought to you for free and open access by the Center for Regional Heritage Research at SFA ScholarWorks. It has been accepted for inclusion in Index of Texas Archaeology: Open Access Gray Literature from the Lone Star State by an authorized editor of SFA ScholarWorks. For more information, please contact cdsscholarworks@sfasu.edu. 


\section{Archaeological Testing and Monitoring in Connection with a Drainage Project at Mission San Juan Capistrano San Antonio, Bexar County, Texas}

\section{Creative Commons License}

\section{(c) (1) \&}

This work is licensed under a Creative Commons Attribution-NonCommercial 4.0 International License 


\section{ARCHAEOLOGICAL TESTING AND MONITORING \\ IN CONNECTION WITH}

A DRAINAGE PROJECT AT MISSION SAN JUAN CAPISTRANO

SAN ANTONIO, BEXAR COUNTY, TEXAS

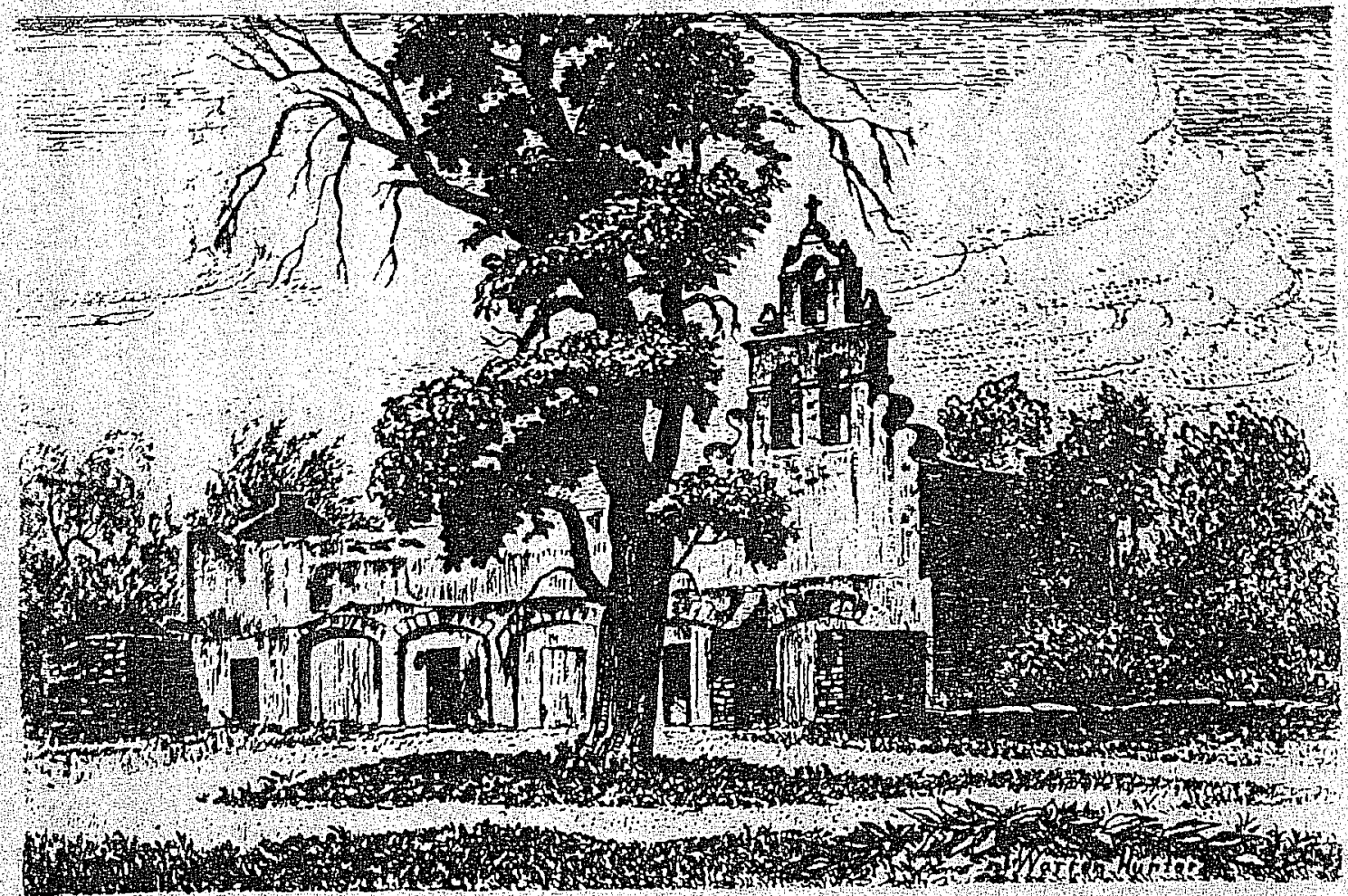

Anne A. Fox

With a Contribution by Barbara Meissner

Center for Archaeological Research

The University of Texas at San Antonio

Archaeological Survey Report, No. 217 



\title{
ARCHAEOLOGICAL TESTING AND MONITORING IN CONNECTION WITH \\ A DRAINAGE PROJECT AT MISSION SAN JUAN CAPISTRANO \\ SAN ANTONIO, BEXAR COUNTY, TEXAS
}

\author{
Anne A. Fox \\ With a Contribution by Barbara Meissner
}

Texas Antiquities Committee Permit No. 1111

Center for Archaeological Research The University of Texas at San Antonio ${ }^{\circledR}$ Archaeological Survey Report, No. 217 
The following information is provided in accordance with the General Rules of Practice and Procedure, Chapter 41.11 (Investigative Reports), Texas Antiquities Committee:

1. Type of investigation: hand-excavated test units and monitoring;

2. Project name: San Juan Capistrano Drainage;

3. County: Bexar;

4. Principal Investigator: Jack D. Eaton: co-principal investigator: Anne A Fox;

5. Name and location of sponsoring agency: San Antonio Missions National Historical Park;

6. Texas Antiquities Committee Permit No. 1111;

7. Published by the Center for Archaeological Research, The University of Texas at San Antonio, San Antonio, Texas 78249-0658, 1993.

A list of publications by the Center for Archaeological Research can be obtained by sending $\$ 1.00$ to the Center for Archaeological Research, The University of Texas at San Antonio, San Antonio, Texas 78249-0658. 


\begin{abstract}
The purpose of this project was to obtain information to guide planning to alleviate drainage problems within the compound of the mission. Four separate areas were tested. Of these, only one uncovered structural remains that might be impacted by the drainage swales planned to carry rain water through the east and south walls and away from the standing structures. At that location, careful measurement of comparative elevations of ground and top of wall revealed that the planned drainage would be possible without damage to the wall. Subsequent drainage work was monitored by the archaeologists to be sure that no other previously unknown structures would be disturbed.
\end{abstract}


TABLE OF CONTENTS

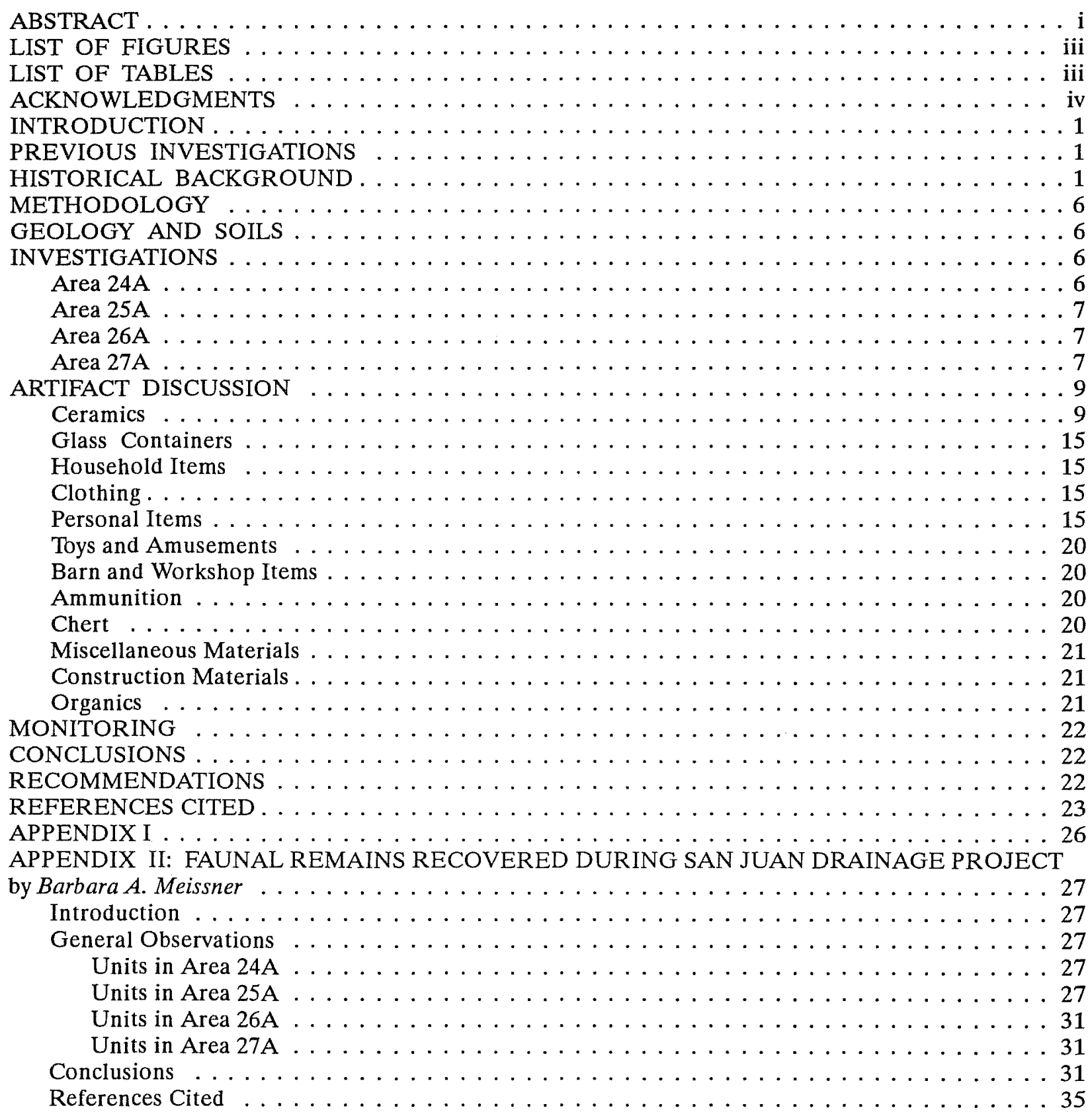




\section{LIST OF FIGURES}

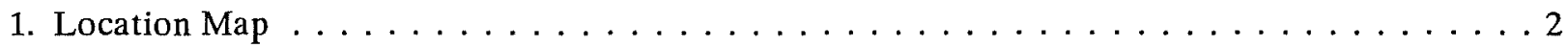

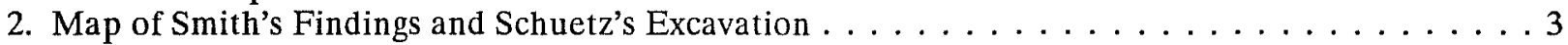

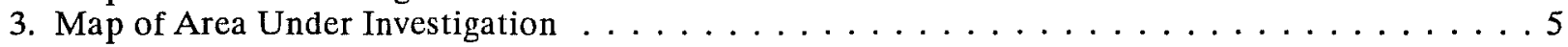

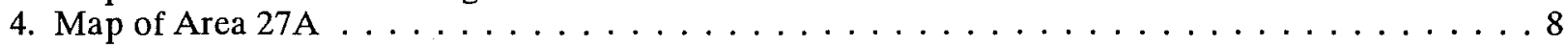

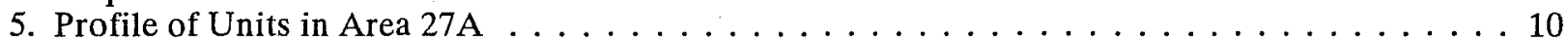

6. Selected Ceramics . . . . . . . . . . . . . . . . . . . . . . . . . . . 14

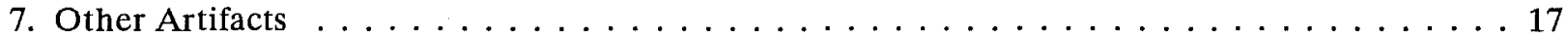

8. Species Represented in Units from Area 24A . . . . . . . . . . . . . . . . . . . . . . . 29

9. Species Represented in Units from Area $25 \mathrm{~A} \ldots \ldots \ldots \ldots \ldots \ldots \ldots$

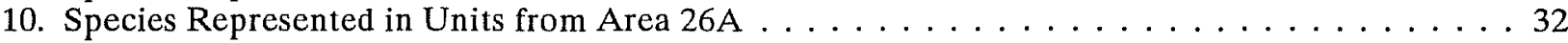

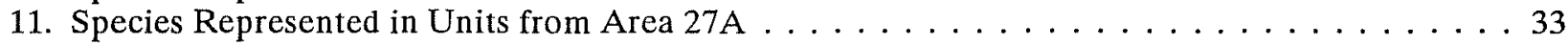

\section{LIST OF TABLES}

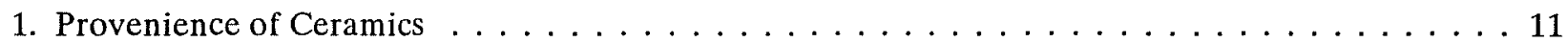

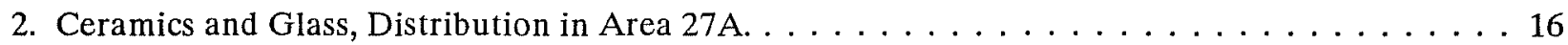

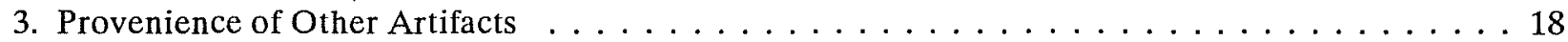

4. Animal Species Identified During San Juan Drainage Project . . . . . . . . . . . . . 28

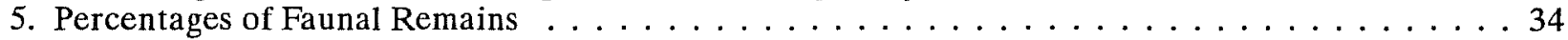

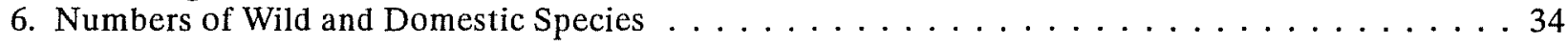




\section{ACKNOWLEDGMENTS}

We are most appreciative of the fine help and cooperation shown the crew by the members of the staff of the San Antonio Missions National Historical Park throughout this project. Superintendent Robert Amdor gave his usual enthusiastic support, for which the author is most grateful. The fact that the project proceeded with dispatch and was so carefully done is due in great part to the help of a number of volunteer helpers, including Marty Morrison, Tommy Nicholson, Jackie Shevlin, and Burnleigh Duke Smith. Drafting for the project report was done by Cynthia Tennis. Santiago Escobedo shared his experience gained during excavation of the Tufa House adjacent to one of the test units. The financial support of the Compadres of the San Antonio Missions National Historic Park is also gratefully acknowledged. 


\section{INTRODUCTION}

In March, 1992, the Center for Archaeological Research (CAR) of The University of Texas at San Antonio (UTSA) conducted testing at four locations on the east wall and southeast corner of Mission San Juan Capistrano in San Antonio, for the San Antonio Missions National Historical Park (SAMNHP). The purpose of the project was to determine if planned surface alterations within the compound in order to direct rainwater out of its central area would impact cultural remains.

Mission San Juan Capistrano has been designated a State Archeological Landmark and is listed on the National Register of Historic Sites. The mission is one of four Spanish colonial missions within the San Antonio Missions National Historical Park. It is located ca. seven miles south of downtown San Antonio, on the left bank of the San Antonio River (Fig. 1). As a registered archeological site, it bears the number 41 BX 5. In compliance with the Texas Antiquities Code, the excavations have been granted Texas Antiquities Permit No. 1111.

The work was accomplished in 10 working days by a crew of eleven. Jack D. Eaton, acting director of CAR, served as principal investigator and Anne Fox as co-principal investigator. Fox directed the field work, which was accomplished by Kevin Gross, Barbara Meissner, Willie Mendez, Shirley Mock, Tommy Nicholson, Cynthia Tennis, and Lea Worcester, aided by four volunteer avocational archaeologists.

\section{PREVIOUS INVESTIGATIONS}

The first professional archaeological investigations done at the mission were directed by Mardith Schuetz of the Witte Museum in 1967 (Schuetz 1968 and 1969). Excavations were done at the northwest corner, the southwest corner, and the unfinished church on the east wall (Fig. 2), in advance of extensive restoration work in these areas. In 1969, Schuetz (1974) conducted investigations beneath the floor of the present church in preparation for restoration work there. Schuetz returned to the mission in 1971 (Schuetz n.d.) to conduct excavations in the first convento in the southwest corner of the compound. Dan Scurlock (1976) directed test excavations to the west of the present church in 1975. James Escobedo conducted excavations at the post-colonial house (presently termed the Tufa House, see Fig. 2, \#28) on the east wall of the mission in 1983 (Escobedo n.d.). These various investigations have all added significantly to the documentary record of the history of Mission San Juan, as related in the Historic Structures Report for the San Antonio Missions (Ivey, Thurber, and Escobedo n.d.).

\section{HISTORICAL BACKGROUND}

Originally founded in east Texas, Mission San Juan Capistrano was moved to San Antonio in 1731, along with two other missions, Mission Purísima Concepción and Mission San Francisco de la Espada. A detailed history of this mission can be found in Fr. Habig's book, The Alamo Chain of Missions (1968) or Schuetz's first volume on the 1967 excavations (Schuetz 1968).

The first structures at San Juan were apparently a row of buildings along the west side containing a granary, an officina or storeroom, and two rooms of a later convento. The first church was a jacal built of upright poles, probably located on the line of the present south wall. By 1762 , there was an enclosed convento in the southwest corner of the compound (see dotted lines in Fig. 2), which included a stone church, a kitchen and dining hall, a friary, and a number of other rooms of miscellaneous uses. By 1772, Indian quarters were being completed at the north end of the compound.

There is no mention in the Spanish inventories of any structures on the present east wall except for a brief mention in 1786 that another church and sacristy were under construction (Lopez 1786). This probably refers to the church ruin on the east wall (\#26 in Fig. 2). Apparently this church was begun a few years after 1772 (Ivey, Thurber, and Escobedo n.d.:184), as part of a renovation which included construction of the east wall north of the church. No mention is made in the inventories of other buildings along this wall; 


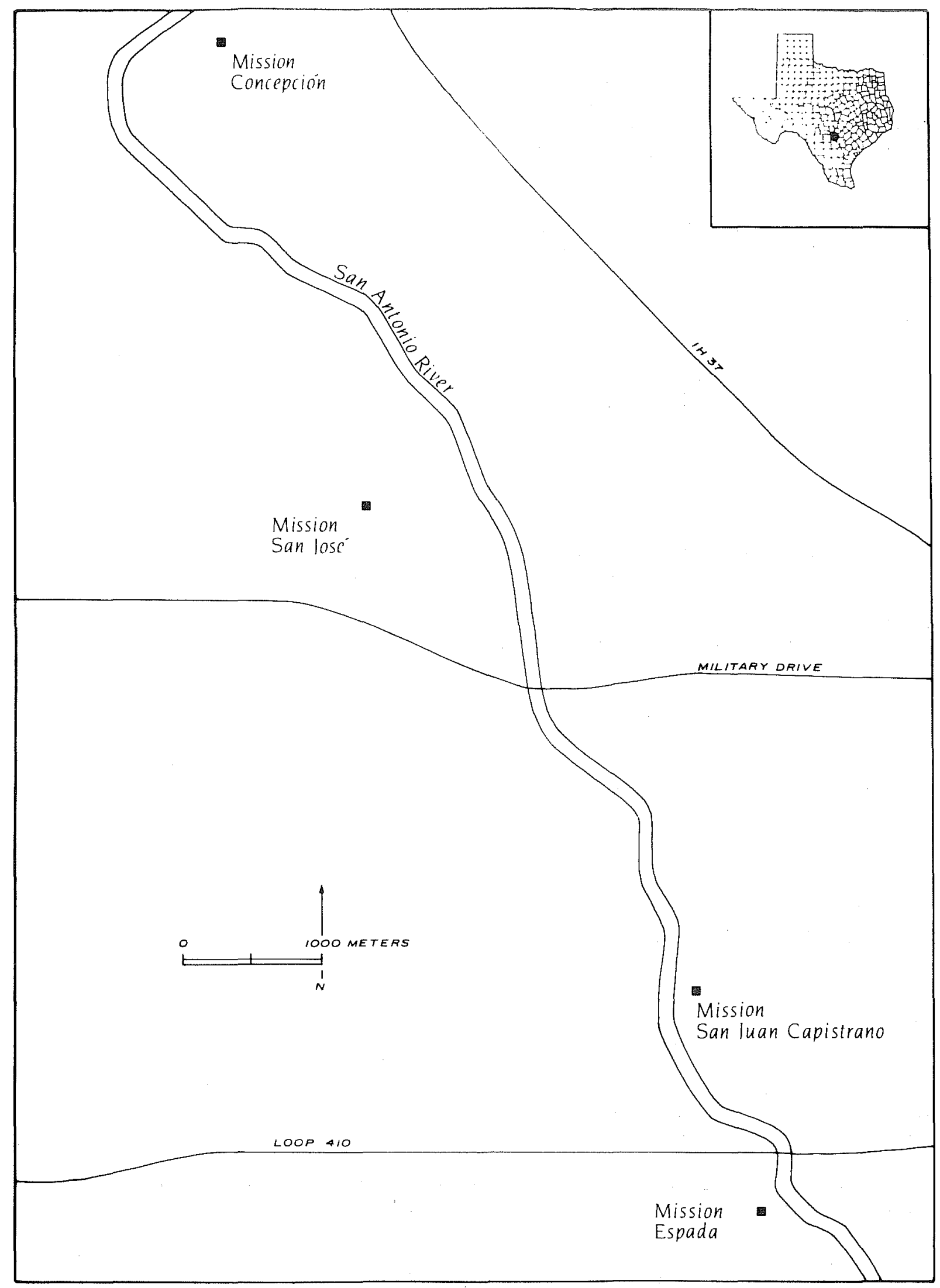

Figure 1. Location map. 


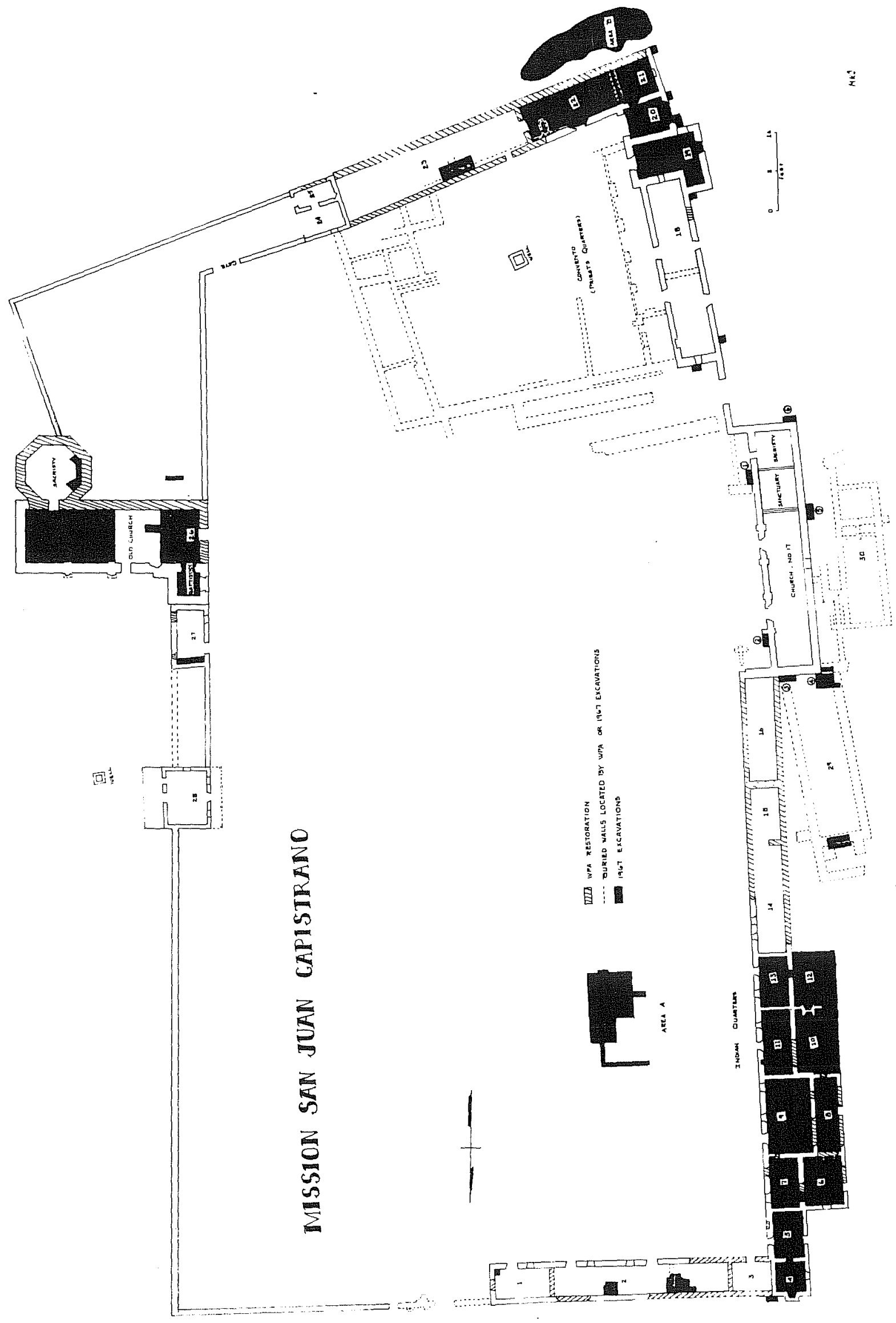

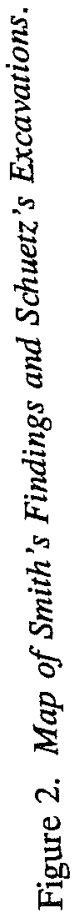


however, Escobedo feels that he found 18th-century wall foundations below the Tufa House foundations. He certainly did recover 18 th- century artifacts from beneath the house.

Mission San Juan was secularized in 1794 (Ivey, Thurber, and Escobedo n.d.:186). In 1823, the administration of the missions was turned over to the local diocese.

Ivey, Thurber, and Escobedo did not conduct detailed deed research on the 19th-century history of land ownership on the east wall. The author decided to delve more deeply into the deed records in order to attempt to explain the artifacts recovered during the testing south of the Tufa House.

At this point, we will focus our attention on the area primarily involved in the test excavations, that is the central and south portions of the east mission wall, and more particularly the area directly north of the old church ruins (Fig. 3).

Apparently no construction took place in this area until after the inventory of 1772 , when the church was begun (Ivey, Thurber, and Escobedo n.d.:184), and the east wall was extended to the northeast corner of the compound, paralleling the Indian quarters across the way. No descriptions have been found to indicate whether there were any structures on this section of the wall during the mission period. An appraisal of houses and walls of the mission in 1824 (BCAMR 15:2) describes a room with stone walls eight varas long and four wide, with a grass roof, directly north of the church (\#27 on Fig. 2). In May of 1827, José Maria Diaz was living in this house, having added another room and eight varas of wall (BCA Roll 130:694-696). In July of that year, he bought the house ( $B C A M R 27)$. A valuation of the house in that same year describes it as "constructed of rock and roof of morillos, and twelve varas of wall" (Schuetz 1968:261). Diaz' deed was officially recorded on November 12, 1830 (BCDR E2:3).

No mention is made in any of these documents of structures standing to the north of Diaz. However, on March 29, 1849, José Maria Cardeñas sold the next lot north of Diaz to Manuel Sosa (BCDR H1:153). The lot, 14 varas wide, contained a house. No description has been found of the house or when it had been built. On November 16, 1867, Sosa's son Rafael sold the lot (no mention of a house) to Gregorio Martínez (BCDR U1:318).

By 1873 , the Diaz children had divided their father's property between them, the northern six varas going to Anselmo Diaz. In that year, Anselmo sold this lot to Gregorio Martínez ( $B C D R \mathrm{X} 1: 313-314$ ), thus enlarging Martínez' lot to 20 varas in width. Measuring off the approximate lot widths on a present-day drawing of this portion of the mission wall (Fig. 3) demonstrates why Martínez may have wanted the extra six varas, since it becomes apparent that the south wall of the Tufa House encroaches several feet onto the Diaz lot. The house may have already been mistakenly enlarged too far in that direction, or Martínez may have been planning an addition to his present house. He may even have totally rebuilt the house at this time. Escobedo (1985) in his excavations beneath the house found possible evidence of remodeling of the southern portion as well as hints that the present house may have been built over an earlier one.

Also in 1873, Gertrudes Diaz sold the rest of the family property to Francis Guilbeau, a local businessman, who had already bought the de Leon lot north of Martínez in 1869 (BCDR U2:495), and the land south of the church in 1858 ( $B C D R$ P2:498-499). He later bought the church lot from Bishop Pellicer in 1876 $(B C D R$ 1:581). Apparently Guilbeau never acquired the Martínez property, although he managed to acquire all the rest of the land around the mission compound before his death in 1879. In 1880, all of Guilbeau's San Juan property was sold by the family, through Thomas J. Devine, Trustee of the estate, to Celestine Villemain. Included in this sale were the irrigated lands to the south of the mission as well as all the compound properties except the Martínez lots (BCDR 16:229-232).

In 1881, Gragorio Martínez and his wife sold their house and lot to José Cassiano for $\$ 500(B C D R 12: 198)$. Cassiaño in turn sold the property in 1888 to Louis Bergstrom for $\$ 250$ (BCDR 50:502), which would seem to indicate that Cassiaño had not taken very good care of the house. Apparently, people were still living around the plaza as well as in the vicinity on farms and ranches in 1884, when a newspaper account describes 


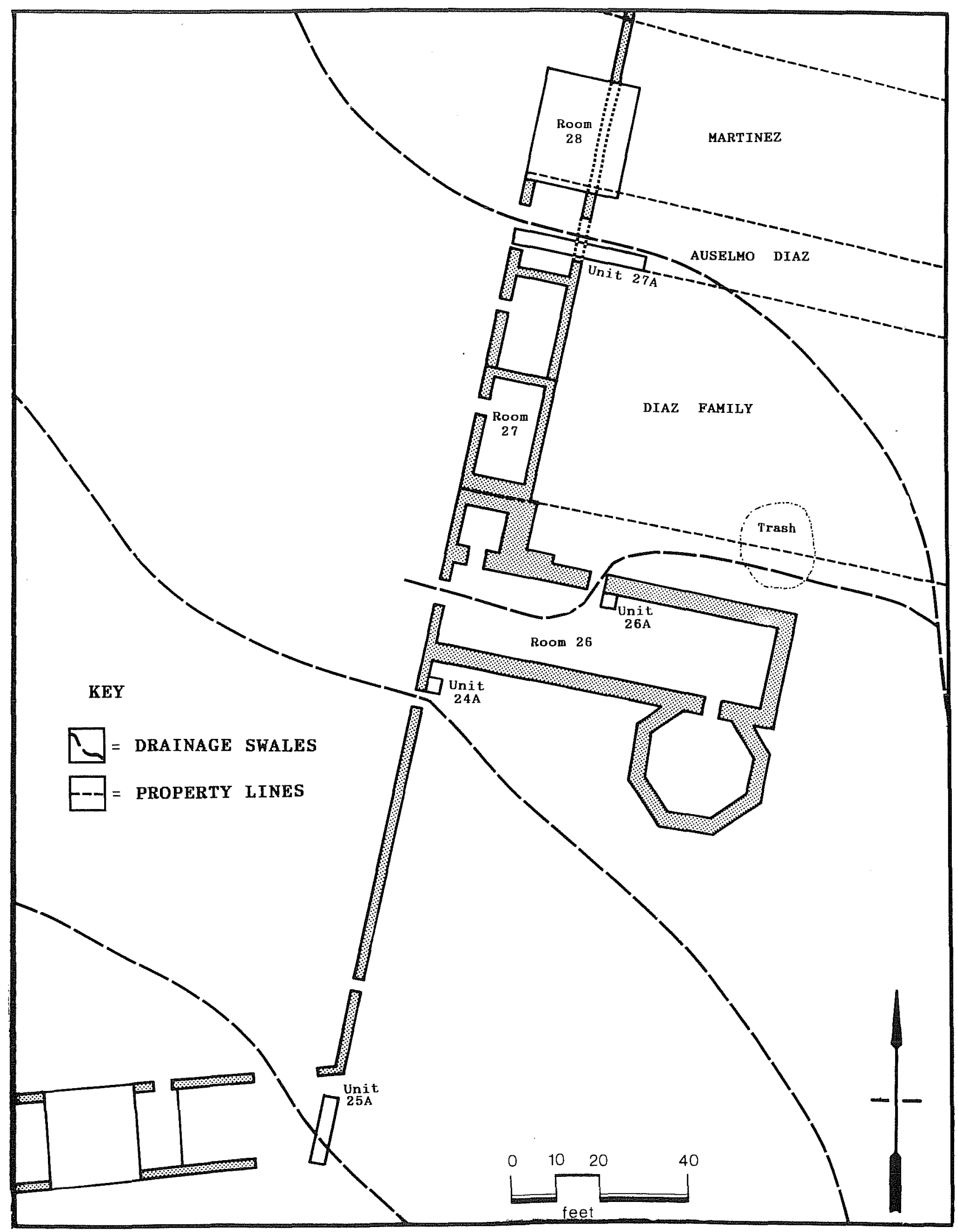

Figure 3. Map of Area Under Investigation. 
the citizens of San Juan "clearing off and raking over the plaza, where they gather every Sunday" (San Antonio Express Feb. 15, 1884).

A description of the compound in 1908 mentions that people are still living in the northwest corner structures (Callahan 1908:40) but does not mention the Tufa House or the Diaz house. Apparently, people moved into and out of the mission structures at will, without the formality of a lease or the payment of rent to the landowner (Corner 1890:21). An aerial photograph of San Juan in the 1920s (on file at SAMNHP Headquarters) shows that both houses are roofed and apparently occupied at that time.

The Tufa House seems to have been occupied off and on until the mid-1940s (Richter 1983), at which time electricity was installed in the house (Escobedo 1985). In 1963, Edgar Byrum lived there briefly in exchange for taking care of the site for the archdiocese (Bily 1963).

\section{METHODOLOGY}

The Scope of Work specified the areas that would need to be tested, based on the plans for shallow drainage swales to be cut through the center of the mission compound (Fig. 3). A series of one meter squares was to be used as a basis for the investigations. Since all the maps used in planning the drainage and most of the previous archaeological excavations done at San Juan used feet and inches, we decided to use three-foot squares in various combinations in order to test the required areas. Excavation was done in six-inch levels, except where a soil change was found, in which case measurements were adjusted to record this. All soil removed was screened through $1 / 4$-inch wire mesh screens. Excavations were carried to sterile soil.

A unit datum was maintained at the northwest corner of each square, with elevations of each datum determined by transit and recorded on the project maps. The elevations were tied into the surveyors' elevations recorded on a map provided by the Park (Bain McCrary Bain, Inc. 1991). The map was also used as a base map for laying out the excavation units. Areas to be tested were assigned arbitrary numbers based on proximity to numbered rooms or walls on the Schuetz map (Schuetz 1968:Fig. 1). Monitoring was done by the author of all drainage construction.

\section{GEOLOGY AND SOILS}

The mission is located on the edge of a terrace above the east bank of the San Antonio River and sits back approximately 200 feet from the river bank. The soil is a component of the Patrick series of the Venus-FrioTrinity association (Taylor, Hailey, and Richmond 1966:General Soil Map). The character of the soils on the site is calcareous loam to light clay loam over stratified alluvium (ibid:68 and sheet 7l).

\section{INVESTIGATIONS}

Location and arrangement of the excavation units were dictated by the proposed location of the drainage swales (Fig. 3).

\section{AREA 24A}

Area 24A was a 3-foot square test unit against the east wall south of the church (Fig. 3). This section of wall was built in the late 19th century (Corner 1890:map of Mission San Juan). The bottom of the wall was found to be only 11 inches below the present surface. The first 6 to 10 inches in this excavation appeared to be fill overlying a layer of gravel. Testing by Schuetz (1968:199) in this area revealed 1.9 feet of fill over this gravel layer. However, the character and content of this fill suggests that it came from somewhere within the mission, since it contained both 18 th- and 19 th-century artifacts. The soil below the gravel resembled that found in the other excavations. Early 19 th-century artifacts were found as deep as 
18 inches, where excavation ceased. All of the soils encountered, both above and below the gravel, were the same brownish gray (5YR 5/1, Munsell Color 1975).

It was determined that slightly lowering the surface in this area would not affect any architectural or cultural features.

\section{AREA 25A}

Area 25A was located at the southeast corner of the mission, where the author observed in 1967 there was a gate into the mission compound (Fig. 2) and what appeared to be a scattering of early 19th-century materials outside the gate. Rainwater accumulating inside the compound was to be directed through this area.

A row of 5 three-foot-square units was laid out north to south across this area. Of these, Units 1,3 , and 5 were excavated. These were located so as to cross the line of the south wall of the mission as reported by Harvey P. Smith during the WPA restoration.

No particular concentration of artifacts and no architectural features were encountered in excavations that extended to 30 and 36 inches. Artifacts recovered were not in any particular stratigraphic relationship and were primarily 19th century in date. Soil was identical to that found in Unit 24A.

\section{AREA 26A}

Area 26A consisted of 1 three-foot-square unit within the church ruin, near the north wall doorway through which it was proposed to direct drainage from the interior of the church. Elevations were particularly critical in this area because of the presence of numerous burials beneath the floor of the church. Fortunately, the datum used by Schuetz during her excavations was still in place, and her careful recording allowed us to tie our work into her measurements. Schuetz found a section of finished floor (1968:198) in the entrance of the church at an elevation of 532.5 feet. The top of the highest recorded burial Schuetz found within the church was at 530.6 feet.

Unit 26A was excavated in three levels to 531.27 feet. The first 6-inch level was extremely soft and contained early 19 th-century ceramics. Below this was similar soil containing 18 th-century artifacts. Soil color in each case was 5 YR $5 / 1$.

The conclusion was that the proposed plan to lower a small area within the doorway slightly to facilitate drainage and to add fill to a low area in the east end of the church would not impact burials, and would benefit the structure by eliminating standing water. It was particularly important that this work be done by hand in order not to put extra weight on soft areas in the church floor.

\section{AREA 27A}

Area 27A consisted of a row of 10 three-foot by three-foot units south of the south wall of the Tufa House on the east wall of the mission (Fig. 4). The purpose for the excavations was to determine if any buried architectural features such as wall foundations would be impacted by lowering the surface in this area to allow the drainage from the compound to flow through this gap in the above-ground walls. Units $1,5,6$, $7,8,9$, and 10 were excavated, limiting the work to the expected locations of walls and other architectural features. This was based on information gained from the work of Escobedo at the Tufa House, which indicated that the original east wall of the mission at one time extended beneath the house (Escobedo 1985). 

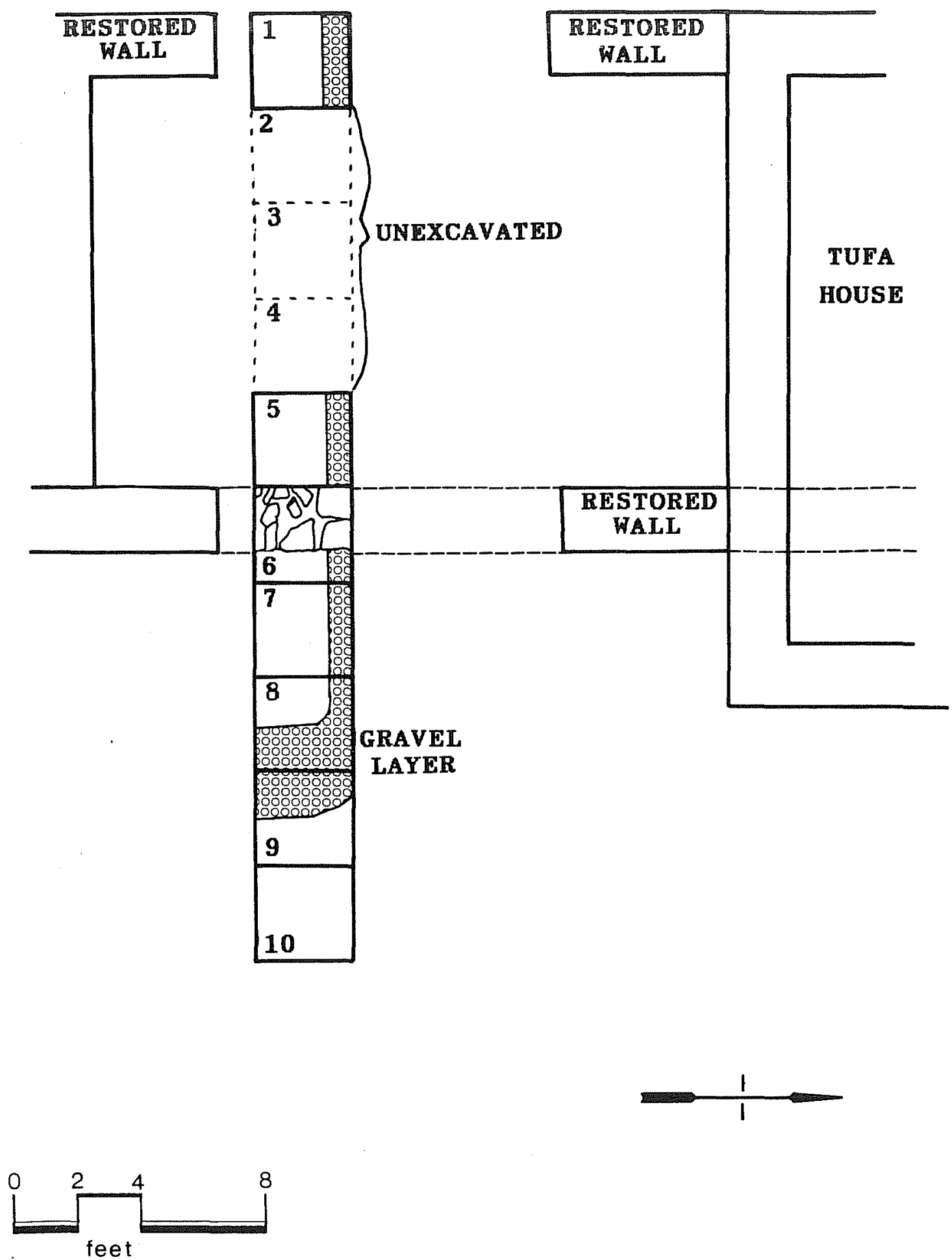

Figure 4. Map of Area 27A. 
Excavations in Units 1, 5, 6, 7, and 8 were excavated to 18 inches, into sterile soil which was encountered at about 15 inches. The soil in the upper level was grayish brown (5YR 5/1) sandy loam, which changed very little except to grow more moist as the excavation went deeper. Artifacts in the first level were primarily 19th century in date. Eighteenth-century artifacts increased in the second and third levels, as did animal bone fragments.

At 3 inches, a section of a gravel walkway was found to intrude ca. 10 inches into the unit from the north. The south margin of this feature was reinforced by a $3 / 4$-inch by $21 / 2$-inch board set on edge. The walk extended through Units $1,5,6,7,8$, and into 9, and then appeared to turn toward the south parallel to the outer edge of the east wall of the mission. The gravel was found to be ca. 3 inches thick in unit 1 , gradually thinning out toward the east (Fig. 5).

The only other feature encountered was the buried foundation of the original east wall of the mission, which extended as we had anticipated in line with the restored portion directly to the south and the buried portion beneath the Tufa House. The top few stones of this wall foundation were encountered at about 3 inches beneath the surface. These were found to be loose remnants on top of a solid wall which started at 6 inches below the surface and extended to about 15 inches. The stones of this wall were carefully arranged, but did not appear to be purposefully shaped, and were laid up with sand and lime mortar. The wall was 24 inches wide. After some discussion, it was decided that lowering the surface to the level of the top of the foundation in Unit 6 would be sufficient change in elevation to allow the planned drainage through the area, without damaging any important cultural resources.

No trace of a wall foundation was found where the west wall would be expected to be in Unit 1 . There did appear to be some disturbance in the spot where we anticipated to find the wall, and it is likely that the stones have been removed for use elsewhere. Absence of any clear stratification in the deposits and the presence throughout the area of fragments of flagstone that may once have been part of a floor surface, suggest that considerable stone robbing has taken place in this area. Escobedo (1985) found a similar situation in his test trench just outside the south wall of the Tufa House.

\section{ARTIFACT DISCUSSION}

\section{CERAMICS}

Ceramic sherds are particularly useful for analysis because of the regularity with which many types came into and went out of style. An archaeologist who has become familiar with the changing styles through time finds sherds of broken vessels can be most helpful in dating sites and deposits within them.

The various types and varieties of ceramics usually present in Spanish sites in San Antonio have been more than adequately described in previous publications (Schuetz 1969; Scurlock and Fox 1977; Fox 1992). Therefore, in this report they are merely listed according to fabric and finish, and concentration is centered on what they can tell about the dating of excavations (Table 1).

Since the deposits sampled in these test excavations appeared for the most part not to be well stratified, discussion will center on the attempt to differentiate between those of the mission period (ca. 1731 to 1800) and those of the 19th-century inhabitants (ca. 1800 to 1900).

Mission period ceramics include unglazed Indian-made wares commonly referred to as Goliad Ware, which are hand-built, and wheel-turned unglazed vessels. Also found in San Antonio mission sites of this period are sherds from various slipped and burnished, lead glazed, and tin glazed vessels (Fig. 6,a-g) made in Mexico. Nearly every excavation also produces one or two sherds of tin glazed vessels made in France.

Nineteenth-century ceramics include undecorated whitewares (including so-called Ironstone), and whitewares decorated in various ways (Fig. $6, \mathrm{~h}-\mathrm{j}, \mathrm{l}-\mathrm{o}$ ), yellow wares, porcelains, and over-glaze 
UNIT 1

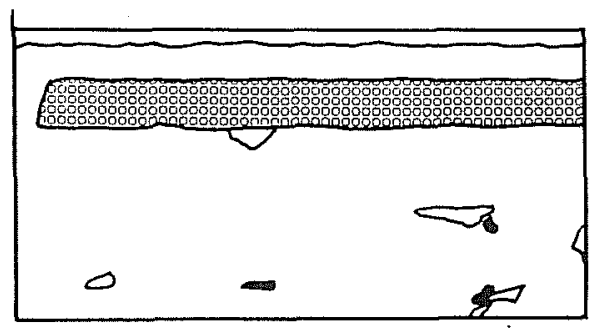

UNIT 5

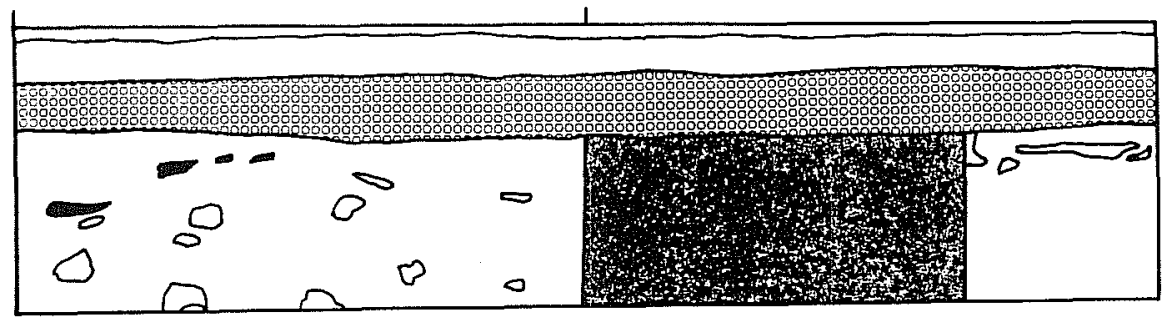

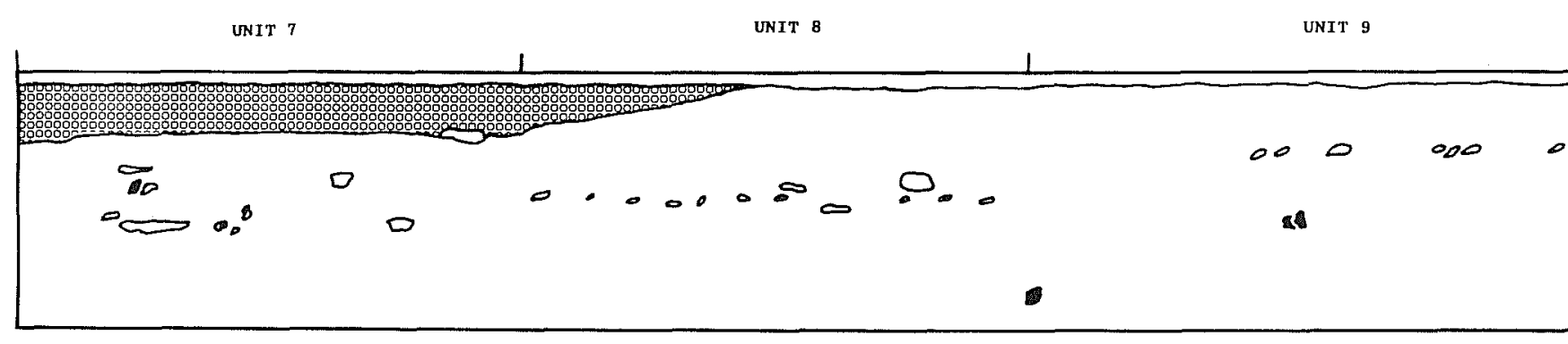

$\overbrace{\text { feet }}^{4}$
UNIT 10

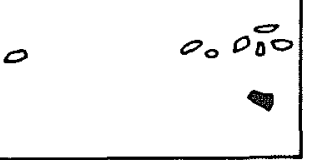

KEY

7. $=$ STONE WALL

FRAVEL PATH

圆 = STONE

国= BONE

Figure 5. Profile of Units in Area 27. North view. 


\begin{tabular}{|c|c|c|c|c|c|c|c|c|c|c|c|c|c|c|c|c|}
\hline 㝴 & 䓂 & $\begin{array}{l}\overline{\mathrm{g}} \\
\mathrm{3}\end{array}$ & 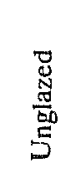 & 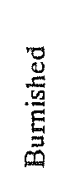 & $\begin{array}{l}\mathbb{J} \\
\mathbb{J} \\
\tilde{J} \\
\mathbb{J} \\
\Xi \\
\Xi\end{array}$ & $\begin{array}{l}\vec{Z} \\
\mathbb{Z} \\
\mathbb{Z} \\
E \\
E\end{array}$ & 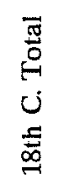 & 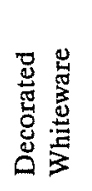 & 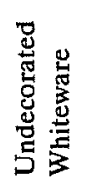 & 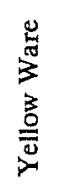 & 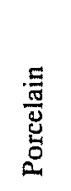 & 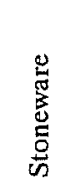 & 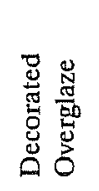 & 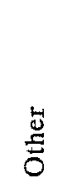 & 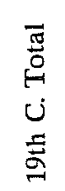 & 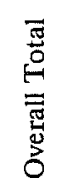 \\
\hline $24 \mathrm{~A}$ & 1 & 1 & 6 & & 2 & 1 & 9 & 3 & 5 & & & 1 & & & 9 & 18 \\
\hline $24 \mathrm{~A}$ & 1 & 2 & 13 & & 6 & 4 & 23 & 5 & 7 & & & 1 & & & 13 & 36 \\
\hline $24 \mathrm{~A}$ & 1 & 3 & & & 3 & 3 & 6 & 9 & 15 & & 1 & & & & 25 & 31 \\
\hline $25 \mathrm{~A}$ & 1 & 1 & & & & & & 9 & 6 & & & 4 & & & 19 & 19 \\
\hline $25 \mathrm{~A}$ & 1 & 2 & 1 & & 3 & 1 & 5 & 11 & 6 & & & 1 & & & 18 & 23 \\
\hline $25 \mathrm{~A}$ & 1 & 3 & 5 & & 3 & & 8 & 11 & 16 & & & 1 & & & 28 & 36 \\
\hline $25 \mathrm{~A}$ & 1 & 4 & 4 & & & 2 & 6 & 2 & 4 & & & & & & 6 & 12 \\
\hline $25 \mathrm{~A}$ & 1 & 5 & 2 & & & 2 & 4 & & & & & & & & 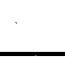 & 4 \\
\hline $25 \mathrm{~A}$ & 1 & 6 & & & & & & & & & & & & & & 0 \\
\hline $25 \mathrm{~A}$ & 3 & 1 & & & 2 & 2 & 4 & 6 & 13 & & 1 & 2 & & & 22 & 26 \\
\hline $25 \mathrm{~A}$ & 3 & 2 & & & & & & 7 & 10 & & & & & & 17 & 17 \\
\hline $25 \mathrm{~A}$ & 5 & 1 & 3 & & 3 & 1 & 7 & 7 & 12 & & & & & & 19 & 26 \\
\hline $25 \mathrm{~A}$ & 5 & 2 & 3 & 1 & 1 & 2 & 7 & 15 & 15 & 1 & 1 & 2 & & 1 & 35 & 42 \\
\hline $25 \mathrm{~A}$ & 5 & 3 & & & 1 & & 1 & 5 & 6 & & & 1 & & & 12 & 13 \\
\hline $25 \mathrm{~A}$ & 5 & 4 & 1 & & 1 & 1 & 3 & 4 & 12 & & & & & & 16 & 19 \\
\hline $25 \mathrm{~A}$ & 5 & 5 & & & 2 & 3 & 5 & 5 & 7 & & & & & 1 & 13 & 18 \\
\hline $25 \mathrm{~A}$ & 5 & 6 & & & & & & 2 & 9 & & 1 & & & & 12 & 12 \\
\hline
\end{tabular}




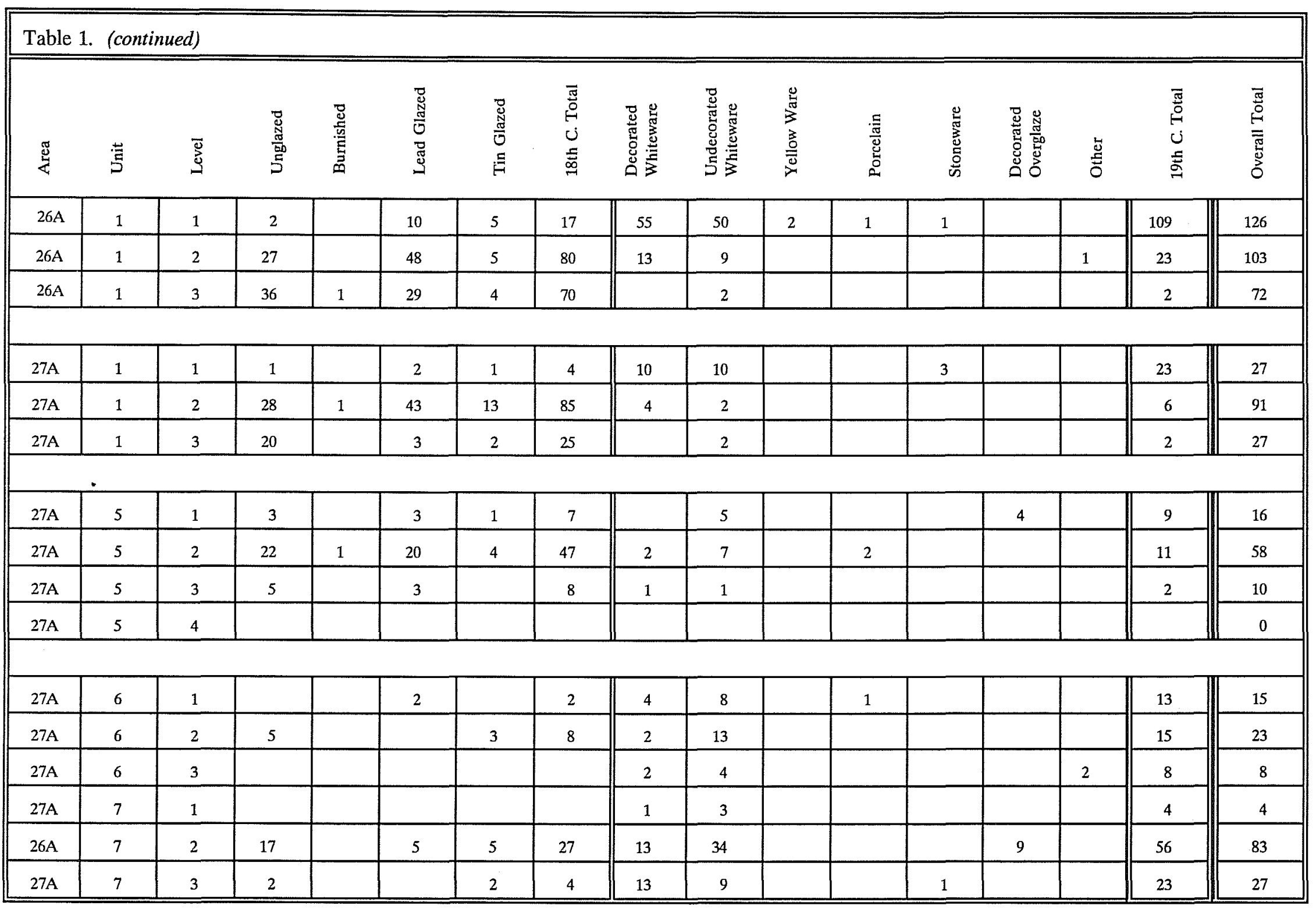




\begin{tabular}{|c|c|c|c|c|c|c|c|c|c|c|c|c|c|c|c|c|}
\hline 丞 & 营 & $\begin{array}{l}\overline{\mathrm{J}} \\
\stackrel{\mathrm{M}}{ }\end{array}$ & 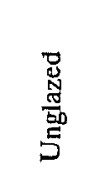 & $\begin{array}{l}\text { 苞 } \\
\text { 总 } \\
\text { 昜 }\end{array}$ & 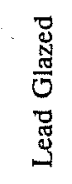 & $\begin{array}{l}\ddot{U} \\
\mathbb{U} \\
0 \\
\Xi \\
\Xi\end{array}$ & $\begin{array}{l}\bar{\pi} \\
\stackrel{0}{0} \\
ن \\
ن \\
\text { 志 }\end{array}$ & 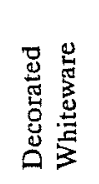 & 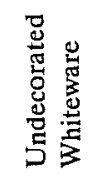 & 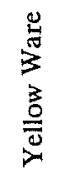 & 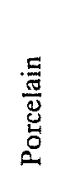 & 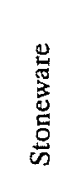 & 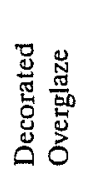 & $\begin{array}{l}\text { 㟔 } \\
\text { D̃ }\end{array}$ & 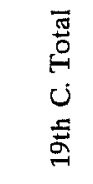 & 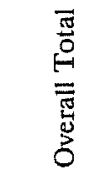 \\
\hline $27 \mathrm{~A}$ & 8 & 1 & & & 2 & & 2 & 2 & 4 & & & & & 1 & 7 & 9 \\
\hline $27 \mathrm{~A}$ & 8 & 2 & 16 & & 3 & 7 & 26 & 39 & 36 & & 1 & & & 3 & 79 & 105 \\
\hline $27 \mathrm{~A}$ & 8 & 3 & 16 & & 1 & 2 & 19 & 16 & 25 & & & & 5 & & 46 & 65 \\
\hline $27 \mathrm{~A}$ & 9 & 1. & & & & 1 & 1 & & 6 & & & & & & 6 & 7 \\
\hline $27 \mathrm{~A}$ & 9 & 2 & 18 & & 3 & 4 & 25 & 10 & 26 & 1 & 5 & 1 & 3 & & 46 & 71 \\
\hline $27 \mathrm{~A}$ & 9 & 3 & 1 & & 1 & & 2 & 8 & 8 & & & & & & 16 & 18 \\
\hline $27 \mathrm{~A}$ & 10 & 1 & & & & & & 4 & 5 & & 2 & & & & 11 & 11 \\
\hline $27 \mathrm{~A}$ & 10 & 2 & 8 & & 4 & 3 & 15 & 39 & 47 & & 8 & 2 & & & 96 & 111 \\
\hline \multicolumn{3}{|c|}{ TOTALS } & 265 & 4 & 209 & 84 & 562 & 339 & 459 & 4 & 24 & 21 & 21 & 9 & 877 & 1439 \\
\hline
\end{tabular}




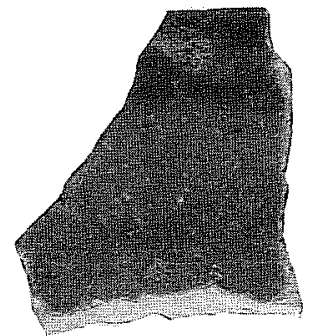

a

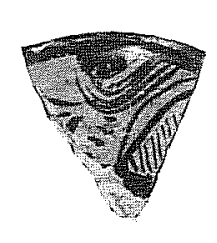

b

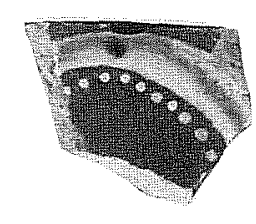

c

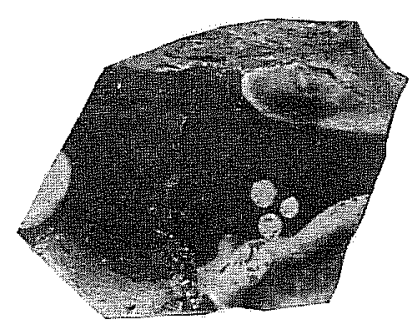

d

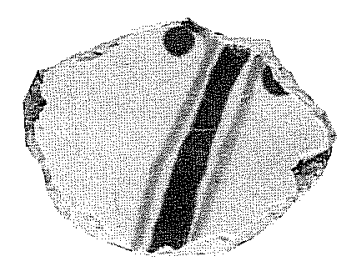

e

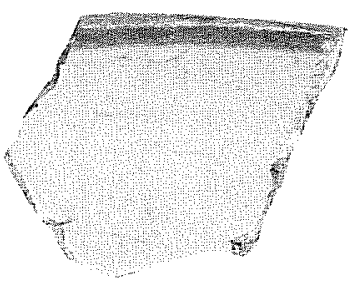

$\mathbf{f}$
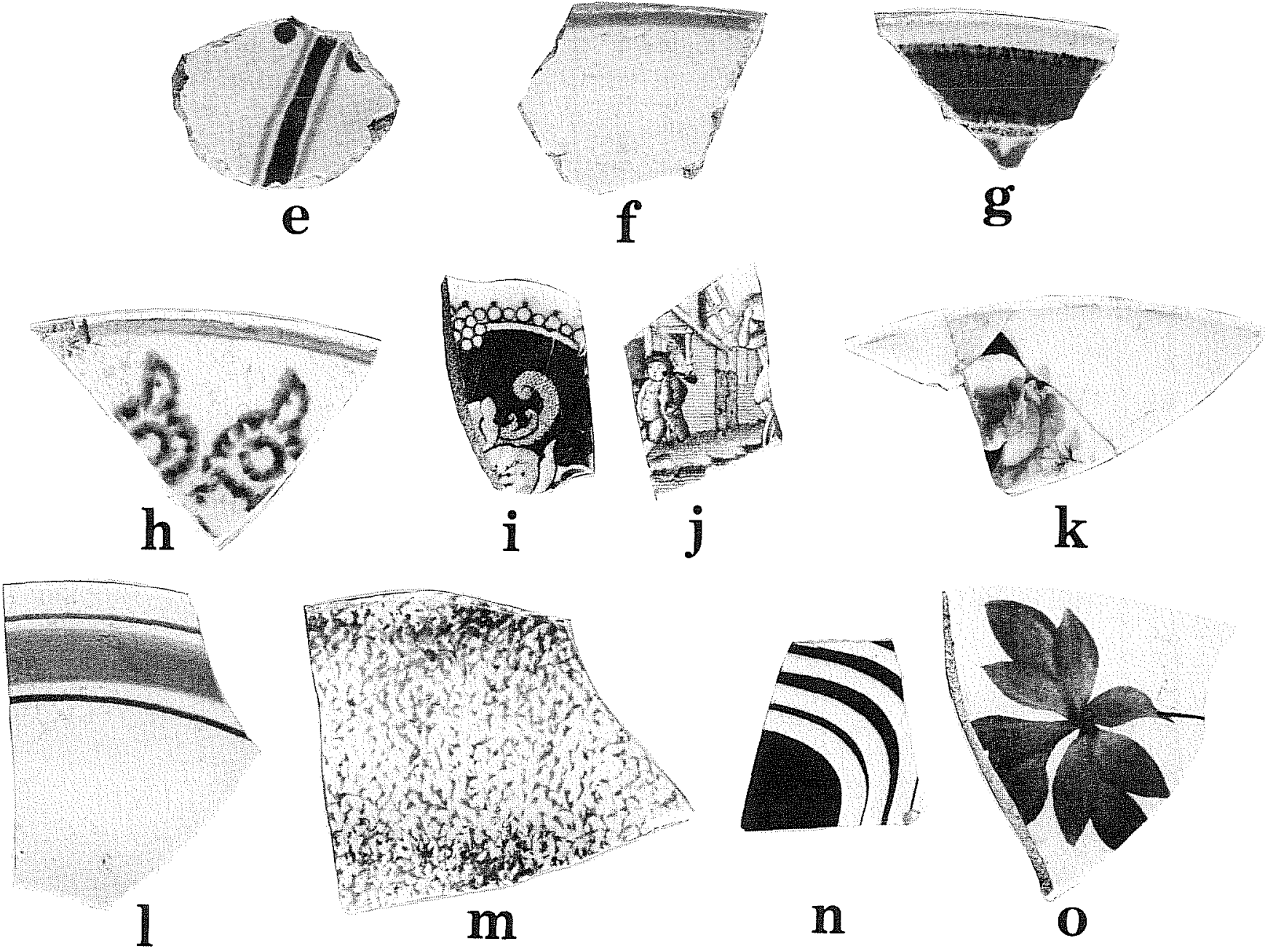

n

O

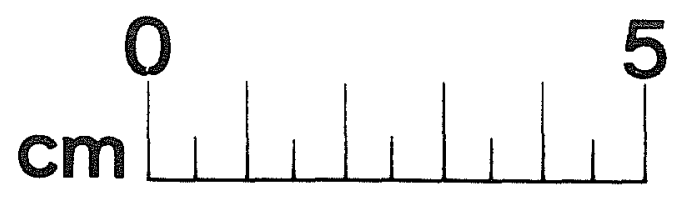

Figure 6. Selected Ceramics. a, lead glazed redware; b, burnished ware; c, lead glazed redware; d, lead glazed redware; e, tin glazed earthenware; $f$, tin glazed earthenware; $g$, tin glazed earthenware; $h$, cut sponge decorated whiteware; $i$, transfer printed whiteware; $j$, transfer printed whiteware; $k$, decal decorated porcelain; 1 , painted whiteware; m, spattered whiteware; n, slip decorated whiteware; o, hand painted whiteware. 
decal-decorated wares (Fig. 6,k). Distribution of these ceramics in the excavations can be seen in Table 2, and where pertinent is discussed in the descriptions of excavations.

Analysis of ceramic and glass recovery from Unit 27A (Table 2) allows some interesting observations. Eighteenth-century ceramics appear to be present in greater numbers west of the wall, particularly in the second, or 6- to 12-inch level, whereas glass and 19th-century ceramics are concentrated outside the wall. The clear division would seem to imply that the wall was present at least into the first part of the 19 th century, and that there may have been a residential structure standing there at sometime in the 18th century. It is interesting that the amount of unglazed ceramic sherds was relatively continuous across the entire deposit, including both the 18th- and 19th-century accumulations. This bears out previous observations by the author that the manufacture of Goliad ware continued past secularization of the missions and into the early 19th century in San Antonio (Hinojosa and Fox 1991:115).

\section{GLASS CONTAINERS}

Glass containers, other than olive-colored wine bottles, are comparatively rare in colonial deposits in San Antonio. Early 19th-century hand-blown medicine bottles are pale blue in color with thin walls and an everted lip. They bear a characteristic pontil mark on their bases. Fragments of such a bottle came from Unit 17A8, Level 2 (Fig. 7,a,b). The base of a brown beer bottle marked "FHGW" from Unit 24A, Level 2 was made by Frederick Hampson Glass Works, Salford 5, Lancaster, England about 1880 to 1890 (Toulouse 1971:202). These are the only time-diagnostic glass fragments found during the project.

\section{HOUSEHOLD ITEMS (Table 3)}

Household items in the collection include numerous crown caps and other types of bottle and can closures, fragments of thin iron, and heavier iron scrap, and several pieces cut from copper vessels. Sheet copper fragments are common in colonial deposits.

Other household objects include a pestle of volcanic stone for use in grinding herbs (Fig. $7, j$ ), a fragment of a bone knife handle, and a flat iron. Three fragments of candle holders made of Goliad (unglazed) ware came from Area 27A, one inside and one outside the east wall. Also in Area 27a was found a drawer pull handle (Fig. 7,e).

\section{CLOTHING}

Sixteen buttons made of metal, porcelain, shell and bone were recovered. Ten of these came from Area 27A. A portion of a hook-and-eye fastener was found in Level 1 of Unit 26A. A sequin was found in Level 1 of Unit 24A.

Two thimbles were recovered, an adult-sized one in Level 2 of Unit 27A9, and a child's thimble (Fig. 7,c) in Level 2 of Unit 25A5. A handle from a pair of utility scissors (Fig. 7,d) was found in Level 2 of Unit 27A9, and the handle from a pair of sewing scissors (Fig. 7,f) from Level 1 in Unit 25A.

\section{PERSONAL ITEMS}

Six glass beads were recovered during excavation. Of these, four can be identified as probably of the Spanish colonial era. They can be described as follows: 
TABLE 2. CERAMICS AND GLASS, DISTRIBUTION IN AREA 27A

Unit 27 A

\section{Ceramics and Glass}

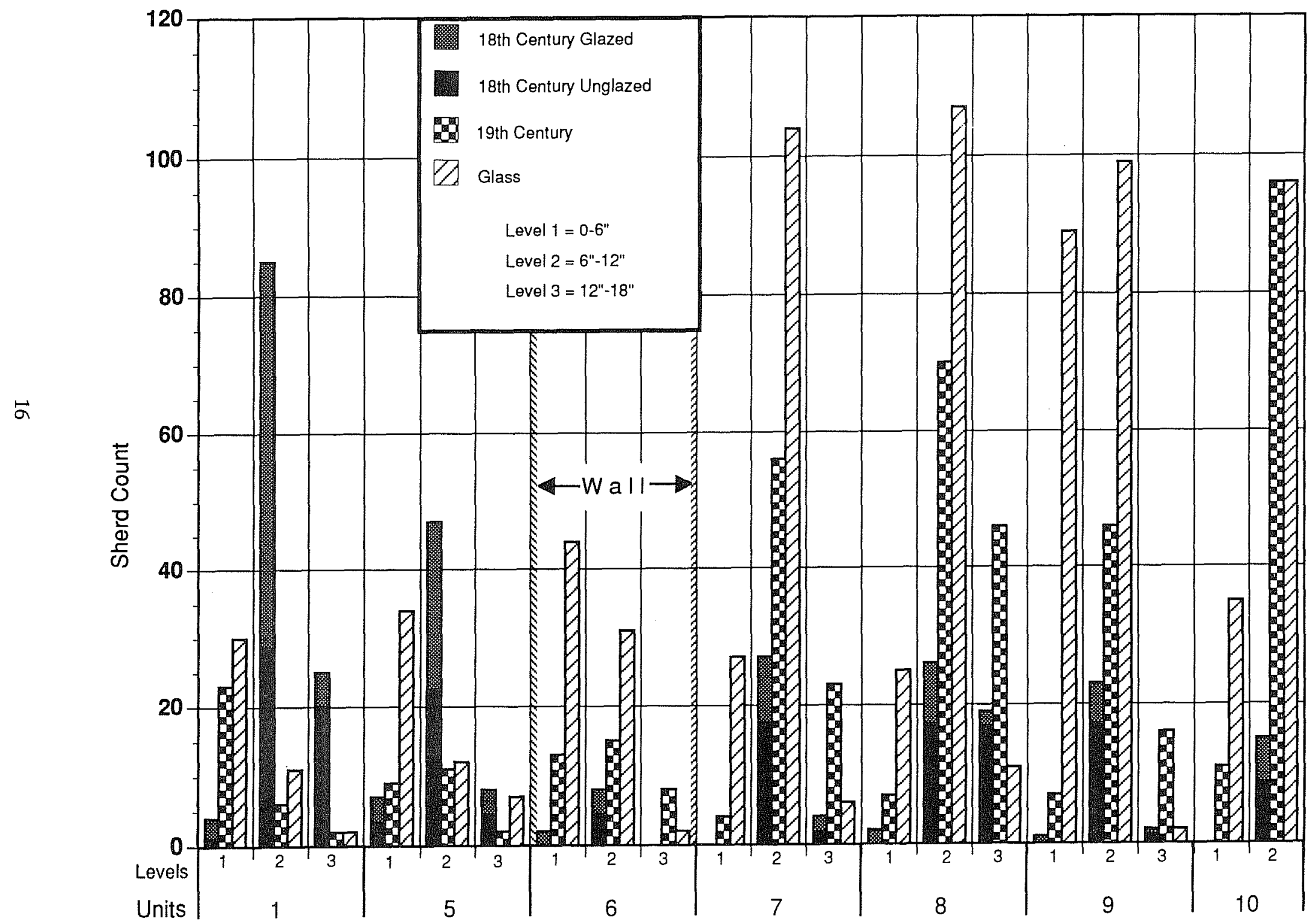



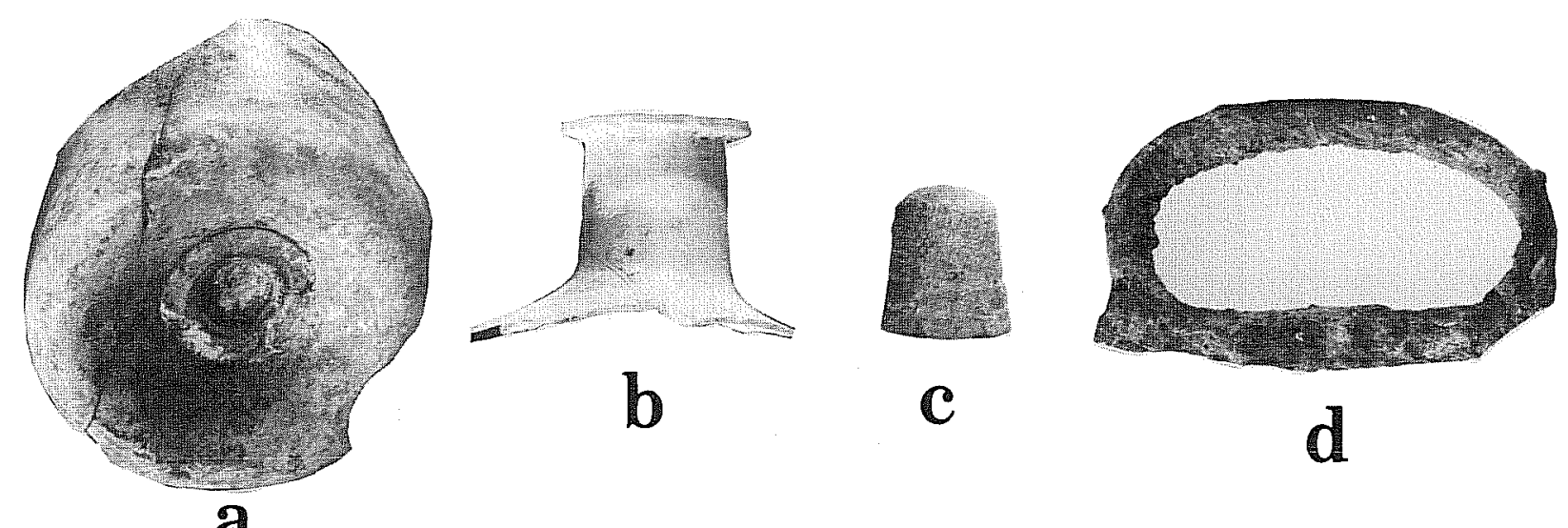

b

c

d
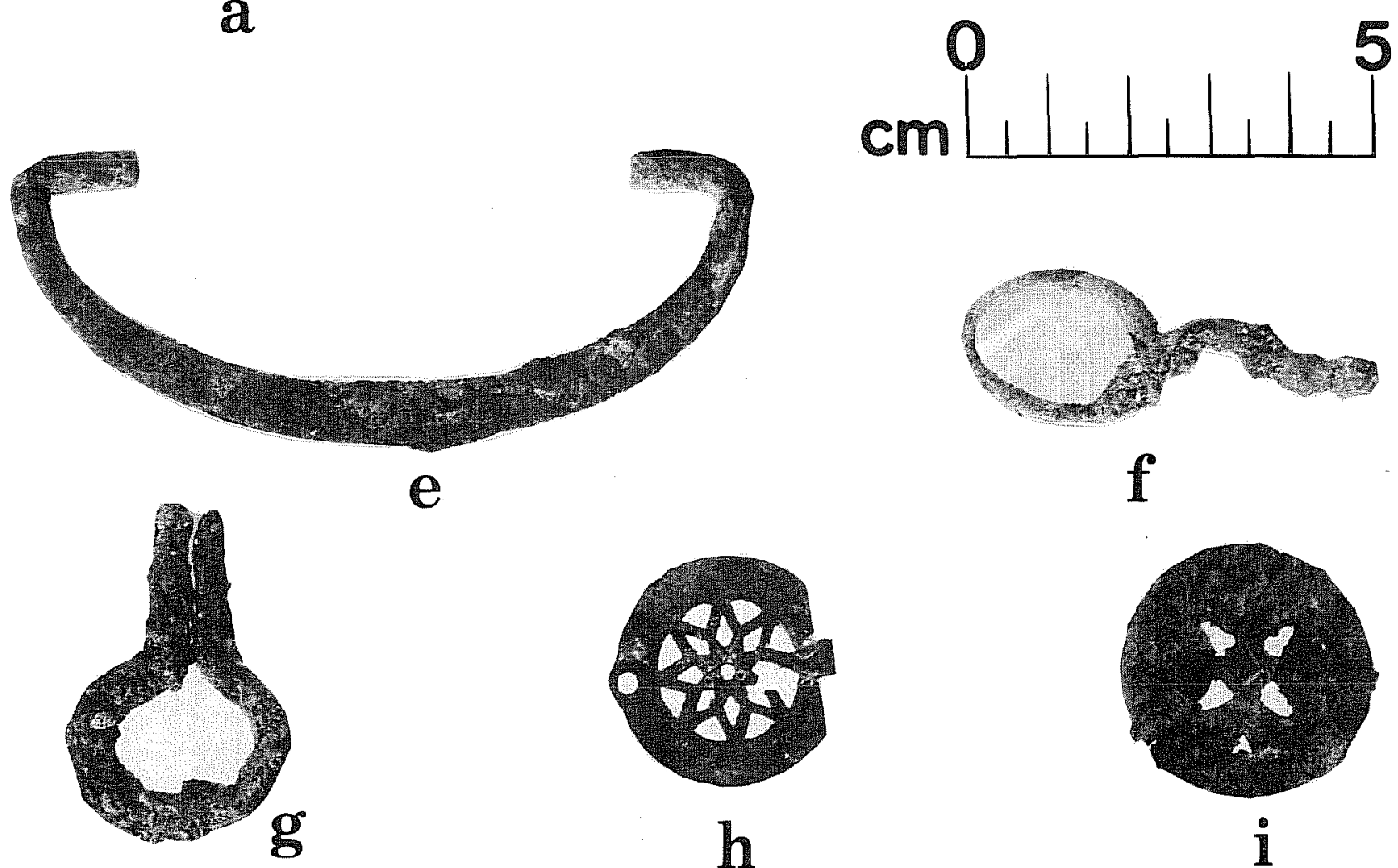

h

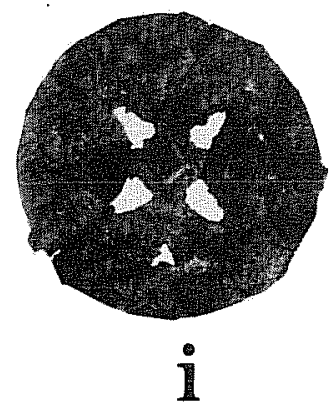

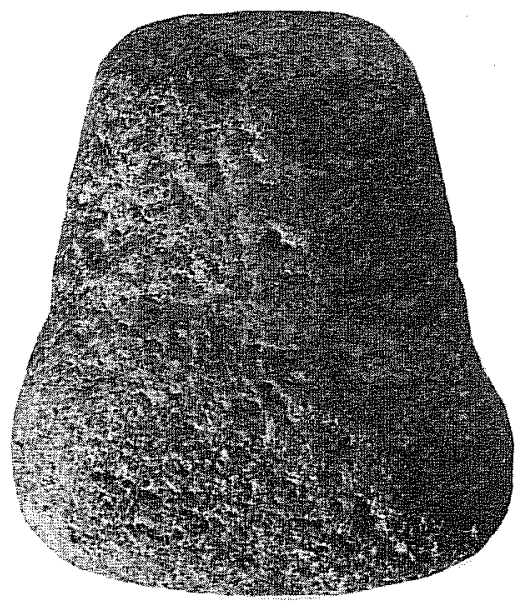

j

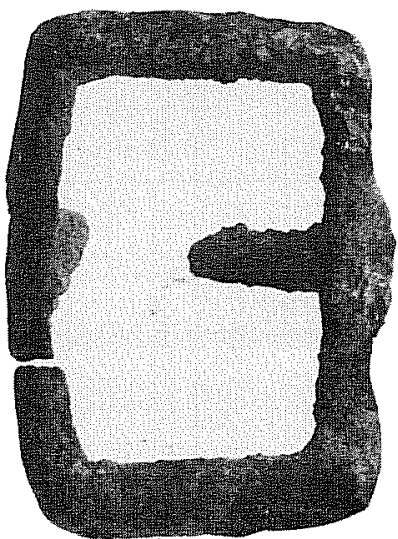

$\mathbf{k}$

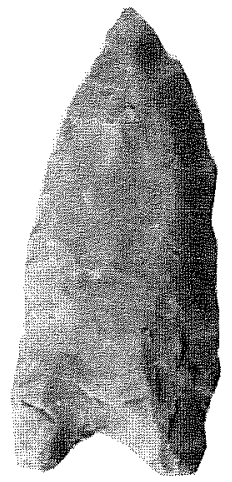

1

Figure 7. Other Artifacts. a, hand blown medicine bottle base; b, hand blown medicine bottle neck; c, child's thimble; d, utility scissors handle; e, drawer pull handle; f, sewing scissors handle; g, Jews harp; h, filigreed copper object; $i$, votive candle base; $j$, volcanic stone pestle; $k$, harness buckle; 1 , projectile point. 


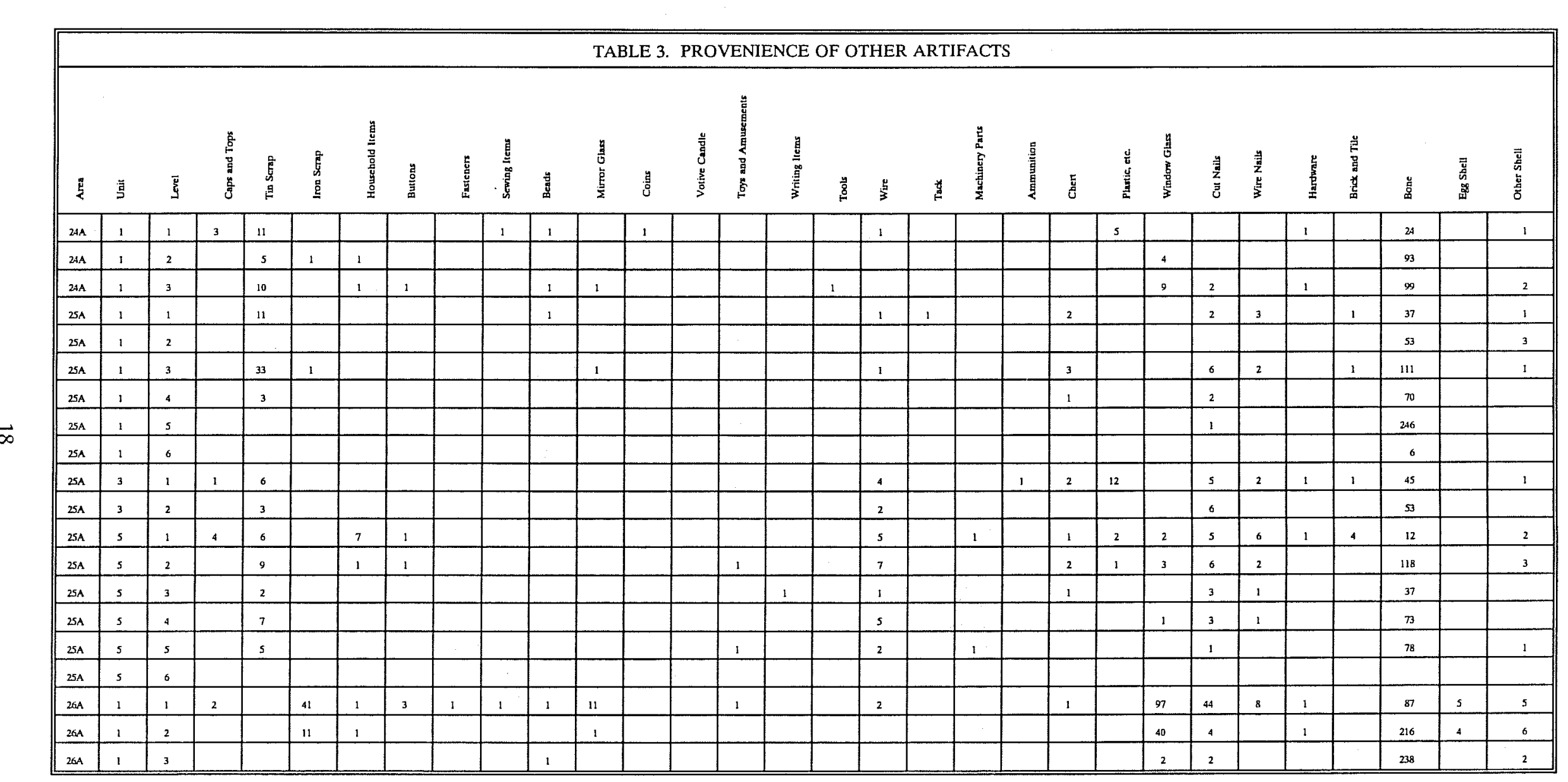




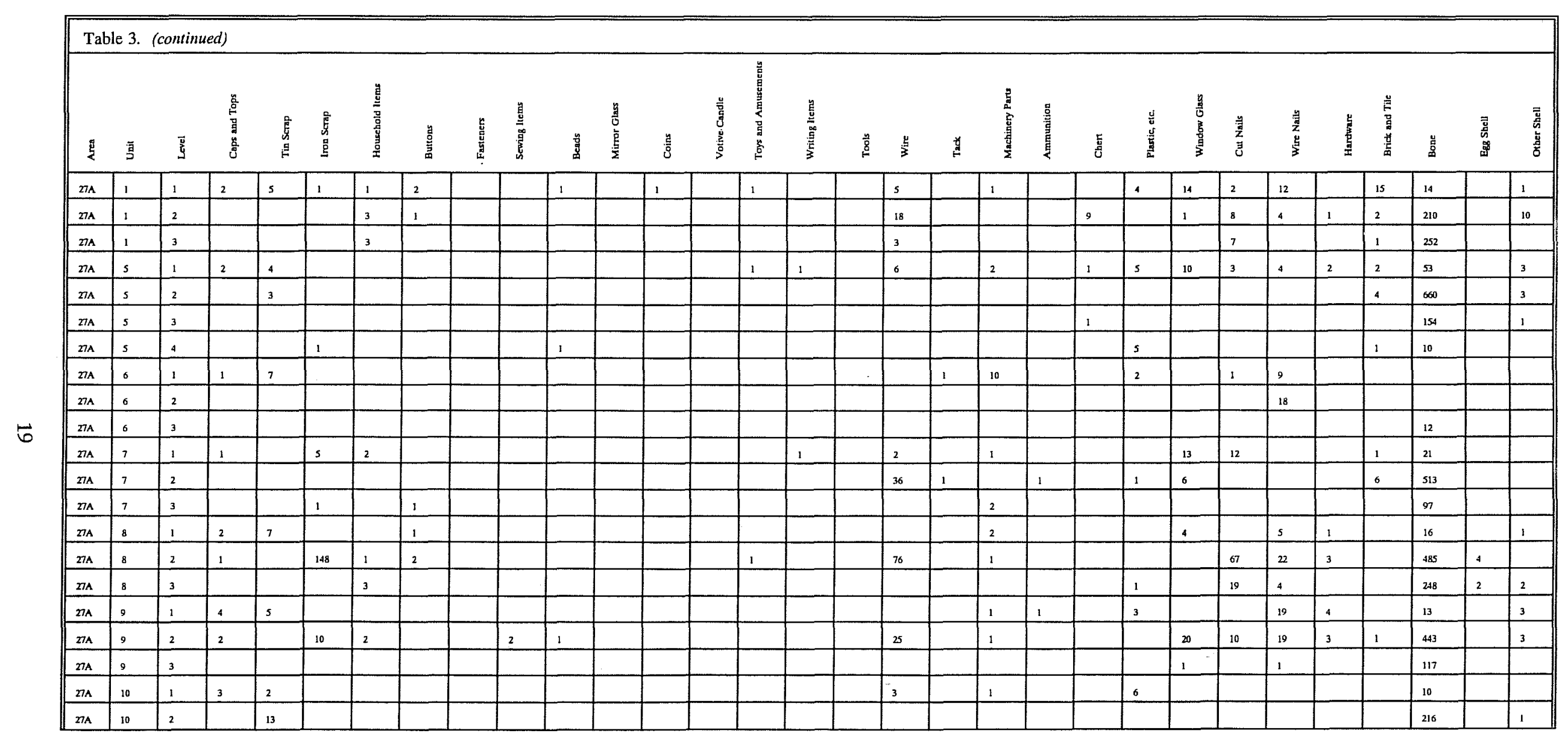


One medium-sized white, semi-opaque, donut shaped garter bead of simple construction. Harris has identified similar beads from the Gilbert Site (1740-1770)(Harper et al. 1967:103). This one was found in Level 2 of Unit 27A9.

One large, aqua, opaque, six-faceted bead of simple construction, was not described by Harris, but was found in a deposit containing colonial artifacts in Unit 24A, Level 3.

Two uneven ring-shaped beads, one of black glass and one of bright blue glass. A similar bead was described by Greer (1967:55) from excavations at the Alamo. The provenience of these is, respectively, Unit 26A, Level 3, and Unit 25A1, Level 1.

Two clear glass beads appearing from their more sophisticated design and construction to be 19th-century examples. One from Unit 26A, Level 1, is circular with one flat face and one face faceted. The hole is drilled parallel to the flat side. The other, from Unit 27A5, Level 4 , is shaped like a watermelon seed, and drilled through the long axis.

An unidentified, thin, filigreed object of copper or brass bears a hole for attachment or suspension (Fig. $7, \mathrm{~h})$. Fragments of mirror glass were found in Levels 1 and 2 of Unit 26A and in the third level of Units 24A and 25A1. Contemporary pennies came from near the surface in Units 24A (1975) and 27A1 (1991). The circular tin base for a votive candle (Fig. 7,i) was found in the first level of Unit 27A1.

\section{TOYS AND AMUSEMENTS}

Two marbles came from the excavations, a broken contemporary glass marble from Unit 27A8, Level 2, and a hand-formed clay marble from Unit 25A5, Level 2. A small fragment of a bone domino came from Unit 25A5, Level 5. A small "Jew's harp" (Fig. 7,g) was found in Level 1 of Unit 26A. In Level 1 of Unit 27A1, a small fragment of a 45 RPM record was found.

Evidence of writing materials present on the site included a graphite fragment from a pencil from Unit 27A5, Level 1, and fragments of slate from Unit 25A5, Level 3, and Unit 27A7, Level 1.

\section{BARN AND WORKSHOP ITEMS}

The only identifiable tool found was part of a woodworking chisel in the third level of Unit 24A. In all, 205 fragments of various kinds of wire were recovered from all the excavations. The tack items include a large harness buckle from Level 2 of Unit 17A7 (Fig. 7,k). Various objects that were machinery parts include several washers, a spark plug, and a number of brass fittings and a valve. In general, these came from the upper levels of the excavations.

\section{AMMUNITION}

Evidence of arms owned and used by San Juan occupants include a musket ball, ca. .41 caliber, for a pistol or a Kentucky rifle (see Fox 1992:Fig. 19), and four 22 shells, and several shotgun shells, all from the first level of excavation.

\section{CHERT}

Eleven chert flakes and fragments were present. These were found primarily in Area $25 \mathrm{~A}$, at the southeast corner, although there were nine in Level 1 of Unit 27A1. A projectile point (Fig. 7,1) from Level 3 of 
Unit 27A5 was probably picked up somewhere in the surrounding fields by mission inhabitants. Such finds are not unusual in mission collections (Hester 1977:10).

\section{MISCELLANEOUS MATERIALS}

Thirty-eight fragments of various types of plastic were recovered from the excavations, primarily from Levels 1 and 2. One aluminum fragment came from Level 1 in Unit 27A5.

\section{CONSTRUCTION MATERIALS}

Distribution of window glass was fairly even across the areas tested. One anomaly of interest is the large amount recovered from the first two levels of the test unit in the church ruin (26A). This would suggest that fill has been brought in from somewhere else on the compound, perhaps when the floor level sank over the numerous burials beneath it. Since the church was never completed (Schuetz 1968:216-218), there could be no other explanation for window glass being present. Another anomaly that tends to confirm this theory is the proportionally large number of cut nails also found there. The fact that these and most of the ceramics recovered from the first two levels were all made in the 19th century would indicate that this filling episode took place sometime around 1900. As might be expected when considering the history of occupation on the mission plaza, 19th-century nails should predominate in most areas. It is interesting that the wire, or 20th-century nails, are more concentrated in Area 27A, where they probably reflect 20th-century additions and repairs to the Tufa House.

Various hardware items were found having to do with construction and maintenance of structures and/or fences. These consisted of bolts, screws, latches, and fencing staples, and appeared to concentrate in the area of $27 \mathrm{~A}$ outside the east wall, in the upper two levels.

One fragment of glazed sewer tile was found in a disturbance at the bottom of Unit 27A1. Similar pipe was being manufactured in south Bexar County after 1892 (San Antonio Daily Express 1892).

\section{ORGANICS}

Animal bone made up by far the largest portion of the artifacts recovered during these excavations. Analysis of the bone was not carried beyond the point of counting fragments and a very general assessment of species represented. Since the areas sampled were so far apart and relatively unrelated, more detailed bone analysis would not have been productive. The largest percentage of the bone was from cattle, with pig and sheep/goat also present. The animals tended to be relatively young, and butchering was done with a hatchet or knife, rather than with a saw.

A few fragments of egg shell suggest that chickens may have been raised by some of the 19th-century occupants. However, surprisingly few chicken bones were found in the excavations.

Mussel shell from the nearby river was present in nearly every excavation unit. Marine shell was also found in Unit 26A, Level 1, and Unit 27A9, Level 1. 


\section{MONITORING}

When the grading began for the drainage swales, the author was present to observe the work and to record any cultural materials or structural remains encountered.

Work began in the church ruin, where ca. 8 inches of soil was removed in a swale from the main doorway leading out through the north wall (Fig. 3). All earth moving was done by hand. The soil removed was spread in the east end of the church to overcome a tendency for rain water to collect and stand in that area.

When this work had been completed, a swale from outside the north wall doorway to a low area around the east end of the church was scraped out slowly with a Bobcat in order to allow careful monitoring in the area, since it had never had archaeological testing. No structural remains were found, but a surface scattering of 1900 to 1940s and some earlier artifacts in this area (Fig. 3) reinforced the author's impression that the Diaz house had probably continued in use until the 1940s (see Appendix for catalog of collection).

The remainder of the drainage swales were accomplished without further incident. Six to eight inches of the fill outside the south wall of the church was transferred inside the east end of the church to help raise the ground level there.

In the area of $27 \mathrm{~A}$, careful removal of a layer of loose stones on top of the east wall (Unit 27A6) revealed a solid section of sandstone slab wall extending north-south across the area, ca. 6 inches below the level of the surrounding surface. The swale was constructed through this area in such a manner as to leave this section of wall undisturbed.

\section{CONCLUSIONS}

Judging by the results of these investigations, a surprising amount of earth moving has been done at Mission San Juan over the years since its construction. In Units $24 \mathrm{~A}$ and $26 \mathrm{~A}$, evidence was found for filling with soil from elsewhere on the mission grounds. In Units 27A1 and 27A5 it appears that stone robbing and general disturbance has been carried to significant depths. In Area 25A it appears that considerable disturbance has occurred, since there was no observable stratification there, and a wall that appears on the early maps has completely disappeared.

Despite the resulting confusion, a surprising amount of information is still available to the archaeologist who is sensitive to the site and to what may be expected to be found on Spanish sites in the San Antonio area. It was gratifying to be able to predict and find the east wall and to be able to establish its exact elevation so as to allow much-needed drainage to be created there.

It is also important that we have now been able to correct the drainage problems within the church ruin so as to help preserve what remains of the walls from future collapse. Problems of drainage control there were apparent as long ago as when the first excavations were under way in 1967 (Schuetz 1968:206).

\section{RECOMMENDATIONS}

The amount of information recovered during this project underlines the importance of having archaeological investigations in advance of any future drainage work at all the San Antonio missions. This mission has had more archaeological investigations than the others in the park, and it is apparent that the backlog of archaeological data now available as a result of these investigations allows more intelligent and useful excavations to be planned on this site. The major importance of careful documentation such as that done by Schuetz in her excavations in the church ruin becomes obvious when we must make drainage decisions that may affect the integrity of the cultural deposits in the future. 


\section{REFERENCES CITED}

Bain McCrary Bain, Inc.

1991

Topographical Survey of Mission San Juan de Capistraño, San Antonio, Bexar County, Texas. Revised Feb. 10, 1992.

Bexar County

Bexar County Archives $(B C A)$

Bexar County Archives Mission Records (BCAMR)

Bexar County Deed Records $(B C D R)$

Bily, Rev. E. F.

1963 Letter to Rev. Charles Herzig, March 5, 1963.

Callahan, E. H.

1908 The Franciscan Missions of San Antonio. Out West: A Magazine of the Old Pacific and New, Vol. 28, Jan - June, pp. 20-49.

Corner, W.

1890 San Antonio de Bexar: A Guide and History. Bainbridge and Corner, San Antonio, Texas.

Escobedo, J. T.

1985 The Post-Colonial House: An Excavation Report. Unpublished manuscript on file at SAMNHP Headquarters.

n.d. Preliminary Report, Archaeology LCS 315. San Antonio Missions National Historical Park. Preliminary draft. On file at SAMNHP.

Fox, A. A.

1992 Archaeological Investigations in Alamo Plaza, San Antonio, Bexar County, Texas, 1988 and 1989. Center for Archaeological Research, The University of Texas at San Antonio, Archaeological Survey Report 205.

Greer, J. W.

1967 A description of the Stratigraphy, Features and Artifacts from an Archeological Excavation at the Alamo. State Building Commission Archeological Program, Report 3, Austin.

Habig, M. A.

1968 The Alamo Chain of Missions. A History of San Antonio's Five Old Missions. Franciscan Herald Press, Chicago, Illinois. 
Harper, L, R. Harper, R.K. Harris, I.M. Harris, E.B. Jelks, and J.N. Woodall

1967 Ornaments. In The Gilbert Site, Bulletin of the Texas Archeological Society 37:87-104.

Hester, T. R.

1977 The Lithic Technology of Mission Indians in Texas and Northern Mexico. Lithic Technology VI(1-2):9-13.

Hinojosa, G. M. and A. A. Fox

1991 Indians and their Culture in San Fernando de Béxar. In Tejano Origins in Eighteenth Century San Antonio edited by Gerald E. Poyo and Gilberto M. Hinojosa. University of Texas Press for the Institute of Texan Cultures at San Antonio.

Ivey, J. E., M. B. Thurber, and J. T. Escobedo

n.d. Of Various Magnificence, The Architectural History of the San Antonio Missions in the Colonial Period and the Nineteenth Century. San Antonio Missions National Historical Park, San Antonio, Texas, manuscript on file.

Lopez, Fr. J. F.

1786 Razon y Informe. Copy made by Josef Sanchez de Lugue in 1789 from the original in Archivo de Secretaria Espiscopal, Monterrey, Mexico. Photostat in Barker Texas History Center, Austin.

\section{Munsell Color}

1975 Munsell Soil Color Charts. MacBeth Division of Kollmorgan Corporation, Baltimore, Md.

Richter, Nellie

1983 Oral History Interview. Tape and transcript on file at SAMNHP Headquarters.

San Antonio Daily Express

1892 To Build Up the Town, Captain Mackey's Latest Effort in that Direction. Monday, October 17.

San Antonio Express

1884 San Juan Mission and Village. February 15, 1884.

Schuetz, M. K.

1968 The History and Archeology of Mission San Juan Capistraño, San Antonio, Texas, Volume I. State Building Commission Archeological Program, Report 10, Austin.

1969 The History and Archeology of Mission San Juan Capistraño, San Antonio, Texas. Volume II. State Building Commission Archeological Program, Report 11, Austin. 
1974 The Dating of the Chapel at Mission San Juan Capistraño, San Antonio, Texas. State Historical Commission, Office of the State Archeologist, Special Report 12, Austin.

n.d. History and Archeology of Mission San Juan Capistraño, San Antonio, Texas. Volume 4. Excavation of the Convento. Manuscript on file, Office of the State Archeologist, Texas Historical Commission, Austin.

Scurlock, D.

1976 Archeological and Architectural Tests at Mission San Juan Capistraño Church, March and April, 1975. Texas Historical Commission, Office of the State Archeologist, Special Report 21, Austin.

Scurlock, D. and D. E. Fox

1977 An Archeological Investigation of Mission Concepción, San Antonio, Texas. Texas Historical Commission, Office of the State Archeologist Report 28.

Taylor, F. B., R. B. Hailey, and D. L. Richmond

1966 Soil Survey of Bexar County, Texas. United States Department of Agriculture, Soil Conservation Service, in cooperation with the Texas Agricultural Experiment Station, Series 1962(12).

Toulouse, J. H.

1971 Bottle Makers and Their Marks. Thomas Nelson, Inc., New York. 


\section{APPENDIX I}

\section{Catalog of Diaz Yard Artifacts}

Ceramic sherds:

1 - lead glaze

1 - 19th-century tin glaze

2 - decal on whiteware

6 - solid color on whiteware (yellow, blue, 2 shades green)

1 - spatter on whiteware

1 - blue on whiteware

1 - painted rim on whiteware

1 - ironstone

2 - undecorated whiteware

2 - stoneware, Albany and Bristol glazes

2 - stoneware bowl with decal

\section{Glassware:}

1 - sherd white glass plate

1 - milk glass canning jar insert

1 - toy green glass plate sherd

2 - sherds clear glass

1 - whole clear glass perfume or lotion bottle

1 - clear nail polish bottle

1 - brown flavoring bottle

1 - clear Avon lotion bottle

1 - sherd aqua glass

Metal objects:

1 - lid rouge container

1 - tin can fragment

1 - Texas automobile license "1939"

1 - dog chain

1 - horse harness ring

Other:

1 - glass marble, $1920-1940$

1 - glass marble, post-1938 (dating information in file at CAR) 


\title{
APPENDIX II
}

\section{FAUNAL REMAINS RECOVERED DURING SAN JUAN DRAINAGE PROJECT}

\author{
Barbara A. Meissner
}

\section{INTRODUCTION}

The following is a general analysis of the faunal remains recovered during the San Juan Drainage Project. A list of identified species is presented and general observations discussed. Since a minimum number of individuals count could not be done, no attempt to discuss relative numbers of species can be made at this time. Faunal remains were identified using the comparative collection at the Center for Archaeological Research and the works of Stanley Olsen (Olsen 1964, 1968).

\section{GENERAL OBSERVATIONS}

A total of 5497 bones and bone fragments were recovered. Table 4 presents a list of species identified. Common names will be used in the following observations.

Cow bone fragments were by far the most common bones; however, the vast majority of the faunal remains were too fragmentary to identify except in general terms.

Butchering marks were found on cow, goat or sheep, and pig bones. All butchering, with only five exceptions, was evidently done with a hatchet, ax, or knife. This might suggest that these animals were butchered by nonprofessional butchers. The five exceptions appear to have been cut with hand saws. They include three cow bone fragments, and two pig bone fragments.

Another characteristic of the butcher marks in this collection was the extensive shattering of all long bones. Only two metacarpals from goats were even partially intact. Though there was the usual fragmentation seen in faunal remains in the archaeological record, much of the shattering of long bones took place while the bone was still fresh. It was clearly the custom of the butchers to extract the marrow from all available bones.

Another general observation is that Unit Levels 2 and 3 in all the areas explored during the project have a much wider variety of species and a much higher number of wild species than is seen either above or below these levels. Below Level 3 the variety of faunal remains becomes very restricted. Only cow, goat or sheep, and chicken bones have been identified in these levels.

\section{UNITS IN AREA 24A (Fig. 8)}

Horse, cow, goat or sheep, fish, and rabbit were the identified species in these units.

\section{UNITS IN AREA 25A (Fig. 9)}

Species identified in this area were deer, cow, pig, chicken, goat, rabbit, unidentified rodent, and an unidentified rabbit-sized animal. Unlike most of the units excavated during this project, there are a number of wild animal species in levels lower than Level 3. Much of the cow bones in Levels 3 and 4 were from immature animals, as evidenced by the unsealed epiphysial joints, including a distal humerus and several vertebral centrums. With the exception of Unit 5, Level 5, in which there are a number of fairly large cow bone fragments, the bone in this area was highly fragmented. 
Table 4: Animal Species Identified During San Juan Drainage Project

\section{Scientific Name}

Domestic Species

Bos taurus
Sus scrofa
Capra and/or Ovis species ${ }^{*}$
Gallus sp.
Equus caballus
Canis familiaris

Odocoileus virginianus

Procyon lotor

Lepus species

Didelphis marsupialis

Sylviagus species

Sigmodon hispdius

Dipodomys ordii
Common Name

Cow

Pig

Goat and/or Sheep*

Chicken

Horse

Dog

White-tailed Deer

Raccoon

Jackrabbit

Opossum

Cottontail Rabbit

Hispid Cotton Rat

Ord Kangaroo Rat

*Differentiation between these two species is difficult at best, and not possible here. 


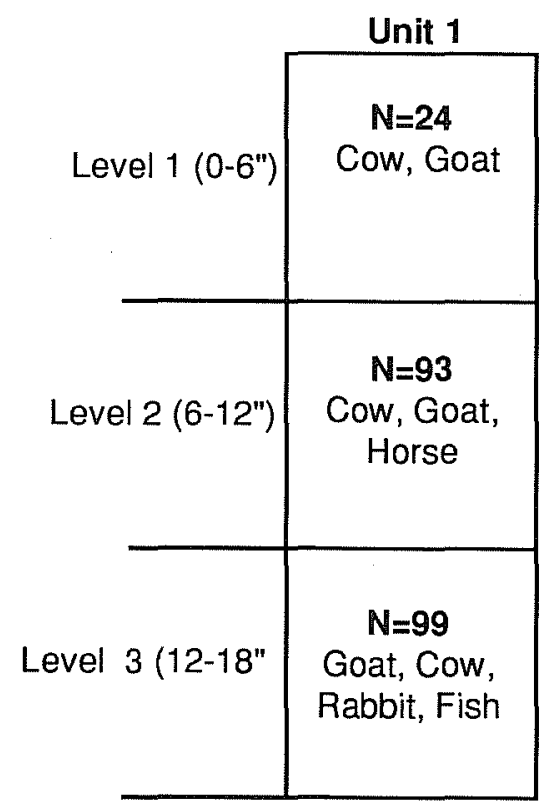

Figure 8. Species Represented in Units from Area $24 A$. 


\begin{tabular}{|c|c|c|c|}
\hline & Unit 1 & Unit 3 & Unit 5 \\
\hline Level $1\left(0-6^{\prime \prime}\right)$ & $\begin{array}{c}N=37 \\
\text { Cow, Pig }\end{array}$ & $\begin{array}{c}\mathrm{N}=45 \\
\text { Cow, rodent }\end{array}$ & $\begin{array}{c}\mathrm{N}=17 \\
\text { Cow, Goat, } \\
\text { rodent }\end{array}$ \\
\hline Level $2\left(6-12^{\prime \prime}\right)$ & $\begin{array}{c}\mathrm{N}=53 \\
\text { Cow, Pig, } \\
\text { Chicken, } \\
\text { small } \\
\text { mammal }\end{array}$ & $\begin{array}{c}\mathrm{N}=53 \\
\text { Cow }\end{array}$ & $\begin{array}{c}\mathrm{N}=118 \\
\text { Goat, Cow }\end{array}$ \\
\hline Level $3\left(12-18^{\prime \prime}\right)$ & $\begin{array}{l}N=1 \\
\text { Cow }\end{array}$ & $\begin{array}{c}\mathrm{N}=213 \\
\text { Cow, Goat, } \\
\text { Pig, }\end{array}$ & $\begin{array}{c}\mathrm{N}=\mathbf{3 4} \\
\text { Cow, Goat, } \\
\text { Rabbit }\end{array}$ \\
\hline Level $4(18-24 ")$ & $\begin{array}{c}\mathrm{N}=70 \\
\text { Cow, } \\
\text { Jackrabbit, } \\
\text { Deer }\end{array}$ & $\begin{array}{c}\mathrm{N}=154 \\
\text { Cow, Goat }\end{array}$ & $N=0$ \\
\hline Level 5 (24-30") & $\begin{array}{c}\text { N=246 } \\
\text { Cow, } \\
\text { Chicken }\end{array}$ & $\begin{array}{c}\mathrm{N}=10 \\
\text { Cow, Goat }\end{array}$ & $\begin{array}{l}N=73 \\
\text { Cow }\end{array}$ \\
\hline Level $6(30-36 ")$ & $\begin{array}{c}\mathrm{N}=\mathbf{6} \\
\text { (too } \\
\text { fragmented } \\
\text { to identify) }\end{array}$ & $N=0$ & $\begin{array}{l}N=78 \\
\text { Cow }\end{array}$ \\
\hline
\end{tabular}

Figure 9. Species Represented in Units from Area 25 A. 


\section{UNITS IN AREA 26A (Fig. 10)}

There was an unusually wide variety of species recovered in this area. Cow, pig, goat, rabbit, turtle, jackrabbit, deer, dog, fish, rattlesnake, a rat-sized animal, and somewhat to our surprise, human bone. A distal left fourth phalange of a human, (i.e. the tip of the left ring finger), was found in Level 2. Of the possible explanations for the recovery of this single bone, two are most likely. The first is that it is the result of a traumatic amputation, lost or deliberately discarded. The other, takes into account that Area 26A is inside the walls of the unfinished church. It was common for burials to be disturbed by subsequent burials inside the sacred ground of a church, where space was at a premium (Schuetz 1968: 213).

\section{UNITS 27A (Fig. 11)}

This was the most extensively tested area, with a total of 7 excavated units. Cow, goat/sheep, pig, racoon, jackrabbit, kangaroo rat, opossum, deer, horse, dog, chicken, turtle, fish, and samples of unidentified rabbit-sized mammal and small bird were recovered. Much of the bone from domestic animals, including cow, pig, and goat, is from immature animals.

Unit 7, Level 2, is remarkable for the large number of mandible and maxilla fragments from several different species, including deer, pig, opossum and goat. As might be expected, there are many cranial fragments in this unit. There are numerous fragments from a very young, possibly newborn goat. Another interesting observation from this unit/level are the relatively few cow bone. There are only three fragments that can be attributed to cow, and all of these are saw cut. They are, with two exceptions, the only saw-cut bone in this collection.

Unit 8, Level 2, contained several deer foot bones and numerous other deer-sized bone fragments, including some very worn deer teeth, horse and kangaroo rat were found, but there is no cow represented in this level. The faunal remains of Level 2 of Units 7 and 8 may be the result of a single dumping incident. The lack of the otherwise ubiquitous cow, and the large numbers of bones from the head and jaws of represented animals, which are rare elsewhere, suggest that this area contains the remains of a specific, somewhat unusual, event.

Area 27A was of particular interest because units were placed both inside and outside the old east wall of the mission. The wall was found in Unit 6. A comparison of faunal material found inside and outside this wall was made (Table 5). Since Unit 6 contained the wall, it is excluded from this comparison.

There appears to be somewhat more bone found outside the wall than might be expected, given the amount of dirt that was excavated on each side. However, the bone found inside the wall is noticeably less fragmented than that outside the wall, which may account for the difference. Table 6 clearly shows more wild animal species found outside the wall than inside. The significance of this observation is not apparent at this time, but may have something to do with the unusually mix of species and of kinds of bones found in Level 2 of Units 7 and 8 that was mention above. It is in Level 2 that most of the wild species are found outside the wall (Fig. 4) This differentiation of material in and outside the wall suggests that is was still standing when the bones found in Level 2 were deposited.

\section{CONCLUSIONS}

The faunal remains recovered during this project show that cow was the most commonly used animal, and that it was probably still being butchered by hand during the time represented by these bone deposits. In addition, goat and/or sheep, pigs, and a few chicken were also common. Long bones were routinely shattered, presumable to extract the marrow. 


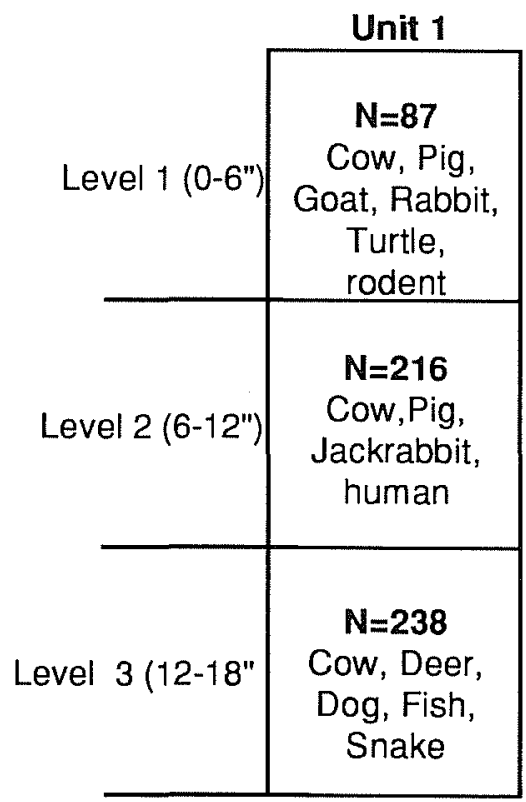

Figure 10. Species Represented in Units from Area $26 \mathrm{~A}$. 


\begin{tabular}{|c|c|c|c|c|c|c|c|}
\hline & Unit 1 & Unit 5 & Unit 6 & Unit 7 & Unit 8 & Unit 9 & Unit 10 \\
\hline Level $1(0-6 ")$ & $\begin{array}{l}\mathrm{N}=14 \\
\text { Goat }\end{array}$ & $\begin{array}{c}\mathrm{N}=53 \\
\text { Cow, Pig }\end{array}$ & 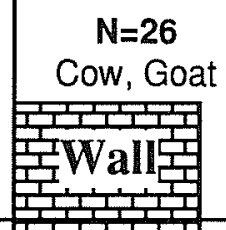 & $\begin{array}{c}\mathrm{N}=\mathbf{2 1} \\
\text { Cow, } \\
\text { Kangaroo } \\
\text { Rat }\end{array}$ & $\begin{array}{c}N=11 \\
\text { Cow, Goat }\end{array}$ & $\begin{array}{c}\mathrm{N}=12 \\
\text { Cow }\end{array}$ & $\begin{array}{c}\mathrm{N}=10 \\
\text { small } \\
\text { mammal }\end{array}$ \\
\hline Level 2 (6-12") & $\begin{array}{c}\mathrm{N}=\mathbf{2 1 3} \\
\text { Cow, Goat }\end{array}$ & $\begin{array}{c}\mathrm{N}=444 \\
\text { Cow, Goat, } \\
\text { Pig, } \\
\text { Jackrabbit }\end{array}$ & 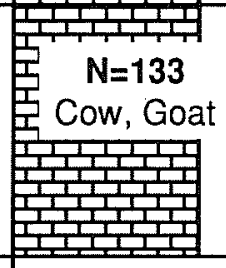 & $\begin{array}{c}\mathrm{N}=513 \\
\text { Deer, Goat, } \\
\text { Opossum, } \\
\text { Jackrabbit, } \\
\text { Pig. Cow }\end{array}$ & $\begin{array}{c}\mathrm{N}=\mathbf{4 8 5} \\
\text { Deer, Horse, } \\
\text { Kangaroo } \\
\text { Rat }\end{array}$ & $\begin{array}{c}\mathrm{N}=443 \\
\text { Cow, Goat, } \\
\text { Chicken, } \\
\text { Dog, Fish, } \\
\text { Turtle }\end{array}$ & $\begin{array}{c}\mathrm{N}=216 \\
\text { Cow, Goat }\end{array}$ \\
\hline Level $3\left(12-18^{\prime \prime}\right)$ & $\begin{array}{l}\text { N=256 } \\
\text { Cow, Pig, } \\
\text { Goat, Dog } \\
\text { Raccoon }\end{array}$ & $\begin{array}{c}\mathrm{N}=213 \\
\text { Cow, Goat, } \\
\text { Pig, }\end{array}$ & & $\begin{array}{c}\mathrm{N}=97 \\
\text { Goat, Deer, } \\
\text { Opossum }\end{array}$ & $\begin{array}{c}\mathrm{N}=253 \\
\text { Cow, Goat, } \\
\text { Dog, small } \\
\text { bird }\end{array}$ & $\begin{array}{c}\mathrm{N}=221 \\
\text { Cow }\end{array}$ & \\
\hline Level 4 (18-24") & & $\begin{array}{c}N=154 \\
\text { Cow, Goat }\end{array}$ & & & & & \\
\hline Level 5 (24-36") & & $\begin{array}{c}\mathbf{N}=10 \\
\text { Cow, Goat }\end{array}$ & & & & & \\
\hline
\end{tabular}

Figure 11. Species Represented in Units from Area 27A. 
Table 5: Percentages of Faunal Remains from Inside and Outside the Wall in Area 27A

$\begin{array}{rrrr} & \text { Inside the wall } & \text { Outside the wall } & \text { Totals } \\ \text { Unit/Levels Excavated } & 8 & 11 & 19 \\ \text { Percent of total for area } & 42 \% & 58 \% & 100 \% \\ \text { Numbers of bone } & 1357 & 2282 & 3639 \\ \text { Percent of total for area } & 37.3 \% & 62.7 \% & 100 \%\end{array}$

Table 6: Numbers of Wild and Domestic Species Inside and Outside the Wall In Area 27A

$\begin{array}{rcc} & \text { inside the wall } & \text { outside the wall } \\ \text { Domestic } & 4 & 5 \\ \text { Wild } & 2 & 8 \\ \text { Total } & 6 & 13\end{array}$


During the period when Level 2 outside the wall in Area 27A was deposited, wild species were still being utilized. Dead dogs were apparently, at least occasionally, thrown into trash heaps rather than given deliberate burials.

Further analysis of these faunal remains and comparison with other collections made at San Juan, and at the other nearby missions, may provide a better insight into the diet of those who once lived there.

\section{REFERENCES CITED}

Olsen, S. J.

1964 Mammal Remains from Archaeological Sites: Part I, Southeastern and Southwestern United States. Peabody Museum, Cambridge, MA.

1968 Fish, Amphibian and Reptile Remains from Archaeological Sites: Part I, Southeastern and Southwestern United States. Peabody Museum, Cambridge, MA.

Schuetz, M. K.

1968 The History and Archeology of Mission San Juan Capistrano, San Antonio, Texas, Vol. 1. State Building Commission Archaeological Program Report Number 10. Austin, TX. 


